\title{
Temperature Dependent Viral Tropism: an explanation of the seasonality and pathogenicity of the endemic
} respiratory viruses

By Patrick D. Shaw Stewart.

Douglas Instruments Ltd., East Garston, Hungerford, Berkshire, RG17 7HD, UK

10 January 2021.

\section{Abstract}

This review seeks to explain four features of viral respiratory illnesses that have perplexed many generations of microbiologists: (1) the seasonal occurrence of viral respiratory illness; (2) the occurrence of respiratory illness year-round in the Tropics; (3) the rapid response of illness to temperature drops in temperate regions; (4) the explosive arrival and rapid termination of epidemics caused by influenza and other respiratory viruses. I discuss the inadequacy of the popular explanations of seasonality, and propose a simple hypothesis, called Temperature Dependent Viral Tropism (TD-VT), that is compatible with the above and other features of respiratory illness. TD-VT notes that viruses can often transmit themselves more effectively if they moderate their pathogenicity (thereby maintaining the mobility of their hosts) and suggests that most endemic respiratory viruses accomplish this by developing thermal sensitivity, in the sense that they normally replicate rapidly only at temperatures below normal body temperature. This allows them to confine themselves to the upper respiratory tract and to avoid infecting the lungs, heart, gut etc. I review biochemical and tissue-culture studies that found that "wild" respiratory viruses often show natural thermal sensitivity within a range that supports organ-specific tropism within the human body, and I discuss the evident tendency for viral strains to adapt their thermal sensitivity to their local climate and season. I also explore the possible misinterpretation of early experiments where volunteers were inoculated nasally with viral samples and then chilled. Next, I discuss the practical implications of the TD-VT hypothesis for preventing and treating respiratory illness. Finally, I note that the hypothesis is very testable and make suggestions for the most important experiments to increase our understanding of the seasonality and pathogenicity of viral respiratory illness.

Keywords: respiratory illness; pathogenicity; virulence; natural selection; colds; influenza; rhinovirus; weather; climate; Tropics; summer; winter

\section{A microbiological problem}

This review focuses on four features of respiratory viral illnesses have been described as problematic [1 Hope-Simpson, 2 Tamerius]:

(1) The seasonal occurrence of viral respiratory illness in temperate regions, with more illness during the colder seasons (Figure 1), including a surge in respiratory illness that frequently appears in the early autumn (Figure 2);

(2) The occurrence of respiratory illness year-round in the Tropics, caused by a set of viruses that are (or appear to be) very similar to those that cause seasonal illness in temperate regions;

(3) The rapid response of illness to weather in temperate regions, where epidemics of colds and flu often follow one or two weeks after cold-weather spells; 
(4) The explosive arrival and rapid termination of many epidemics of influenza and other endemic respiratory viruses.

The near-universal winter seasonality of respiratory viruses is extraordinary, since many completely unrelated viral species share it. The broad characteristics of some important human respiratory viruses that cause illness with winter seasonality are shown in Table 1.

I propose a simple explanation that is based on the idea that viral strains that are less pathogenic are generally transmitted more efficiently.

\section{The proposed solution: the seven premises of Temperature Dependent Viral Tropism}

I suggest that the Temperature Dependent Viral Tropism (TD-VT) hypothesis can explain the four features listed above. The hypothesis is built on seven simple premises:

1. Very pathogenic viruses usually reduce the mobility of their hosts. In well-established endemic viruses, mild or moderately virulent strains are therefore more likely to be transmitted to new hosts than more pathogenic ones. (Note that in human epidemics where fewer than $1 \%$ of infected individuals die, such as COVID-19, differences in host mobility rather than mortality are the main drivers of this reduced pathogenicity.)

2. In the case of respiratory viruses in particular, most moderate their pathogenicity by having one or more temperature-sensitive ( $t s$ ) steps in their life-cycle (Figure 3), such that they replicate best below normal body temperature.

3. This thermal sensitivity allows most respiratory viruses to confine themselves to the nose and throat, where they can cause coughing, sneezing and runny noses, all of which can help to transmit them to other hosts.

4. Less ts strains are more likely to invade the lungs and internal organs, and they are therefore more virulent.

5. If ambient temperature remains stable, or rises, respiratory viruses often remain dormant (defined below) in the respiratory tracts of their hosts. If ambient temperature drops they are likely to become active and may cause respiratory illness.

6. Winter seasonality is a consequence of viral thermal sensitivity.

7. Natural selection allows the level of thermal sensitivity to adapt to local conditions. Thermal sensitivity therefore varies with the seasons and in different climates.

The Nobel laureate André Lwoff suggested part of the hypothesis in 1959, when he noted that the degree of virulence of viruses is often related to their level of thermal sensitivity [5 Lwoff]. In 1979 Richman and Murphy developed this further, discussing many examples of thermal sensitivity in natural and lab-made viral strains, and noting that the near-universal attenuation of $t s$ strains made them good candidates for vaccines [Richman 6]. The full hypothesis was proposed and discussed at length by myself in 2016 , focusing on seasonality and the natural selection of strains with varying degrees of thermal sensitivity and pathogenicity [3 Shaw Stewart]. The same hypothesis was put forward in a clear form by Eccles in 2020, this time concentrating on the advantages of thermal sensitivity to the virus [4 Eccles]. This shorter review summarizes the evidence for the hypothesis, including some recent studies, and discusses its implications for avoiding and treating respiratory illness including SARS-COVID-19.

\section{Dormancy and temperature-sensitivity; definitions of terms.}

In this review, "dormant" means biochemically inactive, or active at low levels. It may imply no viral replication, or low levels of replication. As discussed below, dormant virions may be invisible to the host immune system. (I avoid the word "latent" because this term can refer to viruses that integrate themselves into the host genome, which I am not considering here.) The locations of dormant viruses in the respiratory tract (in, on or between cells) is unknown, and may vary. 
A "mild", "attenuated" or "less pathogenic" virus is normally one that is more ts. Such viruses possess biochemistry that is most active at temperatures below normal body temperature. A "virulent" or "highly pathogenic" virus is one that is less ts, possessing biochemistry that is active at both body temperature and lower temperatures. A highly pathogenic virus is likely to cause respiratory illness at any ambient temperature. A mild respiratory virus is likely to cause respiratory illness only at low ambient temperature.

\section{Background information: the temperature of the respiratory tract in humans}

In 1919, Mudd and Grant, who were American doctors, reported that chilling of the body surface caused a rapid reduction in the blood flow to the lining of the respiratory tract, together with a rapid fall in its temperature [62 Mudd]. More recently, McFadden et al. showed that there is a temperature gradient that runs from the nostrils (which are close to the temperature of the air being breathed) to the lungs (which are at body temperature) [6b McFadden]. For example, during quiet breathing of room air the lining of the upper trachea was at $32.0^{\circ} \mathrm{C}$, but the subsegmental bronchi were at $35.5^{\circ} \mathrm{C}$. The temperature of the respiratory tract fluctuated on each breath, and both breathing colder air and exercise rapidly reduced the temperature. It follows that (1) the temperature of the respiratory tract varies greatly in different parts of the world, and at different times of year. However (2) the temperature of individuals' respiratory tracts is confined to quite a narrow range at any particular time of year and in any particular location.

\section{Conventional explanations of the winter seasonality of viral illness, and their problems}

The most popular explanations of the winter seasonality of respiratory viruses fall into three categories, which I designate as follows (footnote 1): E1, increased crowding of human hosts in winter encourages the spread of respiratory viruses; E2, respiratory viruses survive outside the body longer in cold or dry conditions; E3, the immune defenses of human hosts are weaker during the winter months. [Footnote 1 . Note that these explanations were designated $\mathrm{M} 1, \mathrm{M} 2$ and $\mathrm{M} 3$ in $\mathrm{my}$ 2016 review in Medical Hypotheses, with M denoting mechanism [3 Shaw Stewart]. I have changed the designations to E1, E2 and E3 because the previous designations confused some readers. M4 becomes TD-VT in this review.]

There are difficulties with each of these explanations.

Firstly, E1 would predict that summer sporting events and festivals would be associated with increased transmission of respiratory viruses, which is not the case. Tamerius et al. showed this lack of association for influenza [2 Tamerius]. Figure 4 shows that "Google flu search" did not increase in any country (for which it was recorded) in the Northern Hemisphere during the FIFA 2014 World Cup [6b Google search]. School holidays are also not well-correlated with respiratory illness. For example, children are on holiday in Singapore in December, but this coincides with the yearly peak of influenza [2 Tamerius].

The crowding hypothesis E1 would also predict that colds and flu would be much more prevalent in large cities than in the countryside, which is not the case. Indeed, influenza frequently arrives simultaneously in isolated remote rural settings and nearby towns and cities [7 Hope-Simpson]. A related problem for both E1 and E2 is that flu epidemics arrive simultaneously throughout large geographical areas, particularly widely-separated locations at similar latitudes [8 Hope-Simpson]. Both colds and flu typically follow drops in temperature [9 Van Loghem, 10 Lidwell, 11 Hajat] too rapidly to be due to changes in transmission (see Figure 5).

Focusing on the suggestion that dry conditions encourage transmission, E2 predicts that colds and flu would be reduced during wet weather. Lidwell et al. and Hajat et al. $[10,11]$ found that there was no correlation between upper and lower respiratory tract illness and humidity (or rainfall) in the 
UK. However, both found that upper and lower respiratory tract infections followed cold weather. There are many other examples of this association. (In many cases, humidity is correlated with higher or lower levels of colds and flu, but humidity is itself highly correlated with temperature, and these relationships seem to be driven by temperature [10 Lidwell].) In tropical locations that have rainy seasons, both colds and flu arrive during those seasons [2 Tamerius, and personal communication, Prof B.S. Cavada]. Another problem for the humidity explanation is that some respiratory viruses such as rhinovirus and adenovirus survive better in humid conditions (Table 3), yet they share winter seasonality with virtually all other viral respiratory illnesses. Moreover, a recent study found that influenza viruses supplemented with material from the apical surface of human airway epithelial cells remained infectious irrespective of relative humidity, suggesting that humidity is not an important factor in the winter seasonality of influenza at least [12 Kormuth].

E3 suggests that the immune system is weaker in winter than summer, but this has not been shown. For example, Paynter et al. found that vaccines were slightly more effective in winter than in summer [13 Paynter]. An early study on an isolated tropical island found that colds increased in September when the temperature dropped by only $1-2^{\circ} \mathrm{C}$, from around $24^{\circ} \mathrm{C}$ at night to around $22^{\circ} \mathrm{C}$ [14 Milam] and it seems implausible that such a small temperature drop, starting at a relatively high temperature, could meaningfully depress human immune defenses.

An instance of E3 is the proposal that the winter seasonality of COVID-19 and other viral illnesses is driven by vitamin $D$ deficiency due to reduced sunlight during the winter months. There are several problems here: (1) vitamin D levels typically peak in September in temperate locations (Figure 6) [15 Hyppönen], which is when the autumn surge of respiratory illness often arrives (Figure 2). (2) Vitamin D levels change slowly, typically over a few months (Figure 6), whereas respiratory illness often follows temperature drops within one or two weeks (Figure 5). (3) Colds and flu do not follow overcast weather, and they do not decrease after sunny weather [10 Lidwell]. I conclude that vitamin $\mathrm{D}$ or other deficiencies brought on by a lack of sunshine may contribute to the prevalence of colds and flu in late winter and early spring, but they are unlikely to be the main drivers of winter seasonality.

Note that almost the same set of viruses cause respiratory illness in temperate regions as in the Tropics. Table 2 lists the viruses that most frequently caused hospitalization of children in three studies based at hospitals at different latitudes. There are striking similarities. Moreover, viral respiratory illnesses are rare in mid-summer in temperate regions, but they usually occur throughout the year at moderate levels in the Topics (sometimes with a surge in the rainy season). For example, Figure 7 shows that influenza is almost absent during the summer in northern USA and Sydney (Australia), but it is present year-round in Singapore and during the rainy season in Fortaleza (Brazil). The same trends can be seen in the hospitalization of children caused by respiratory illnesses [ $16 \mathrm{du}$ Prel, 17 Viegas, $18 \mathrm{Chew}$ ] and also in the prevalence of influenza reported by the World Health Organization for the period 1964-75, a time when most people living in the Tropics did not have airconditioning [8 Hope-Simpson]. These trends therefore weigh against E2 and E3, because whatever factors might allow a virus to survive outside the body for longer, or to suppress immunity in the temperate summer, the same factors are likely to have more extreme values in the Tropics yearround. The explanation by TD-VT of the patterns of Tropical illnesses is discussed below.

\section{Does natural selection moderate the pathogenicity of endemic respiratory (and non-respiratory) viruses?}

Figure 8 shows that during the Spanish Influenza epidemic of 1918/19 most European countries experienced a single peak of mortality during a two-month window (October and November 1918). A few countries experienced a smaller peak in early 1920, but, after that, winter mortality returned to normal levels [19 Ansart]. A common explanation for the rapid termination of this epidemic is that almost the whole population was exposed to the virus, and that individuals either died or 
acquired immunity. This review suggests that these explanations are important, but that natural selection of milder strains also contributed to the termination of severe illness.

Observations of viral infections that humans occasionally pick up from other animals, normally vertebrates, supports this interpretation of the data. Such infections may cause mild flu-like symptoms but they may also be highly pathogenic. For example, at least five unrelated groups of RNA viruses have been identified as the causes of hemorrhagic fevers. These are illnesses that cause internal or external bleeding, and are often fatal. Examples include Whitewater Arroyo virus fever, Rift Valley fever, Lujo virus, as well as Argentine, Bolivian, Brazilian, Chapare, Venezualian, Hantavirus, Crimean-Congo, Omsk, Bas-Congo, and Kyasanur Forest hemorrhagic fevers. Hemorrhagic fevers caused by Marburg virus, Lassa fever virus and Ebola virus have been seen to spread between human hosts [20 Wikipedia article]. Other viruses that "spilled over" to humans from other species and caused epidemics with high mortality include Spanish influenza, HIV, SARSCoV-1 and SARS-CoV-2. Clearly these viruses are not yet well-adapted to their hosts, yet they are much more pathogenic than most well-established endemic viruses such as cold viruses, supporting the proposal that selective pressures have resulted in a loss of virulence as viruses adapt to their hosts and become endemic.

The moderation of viral pathogenicity is predicted by the well-known "transmission-virulence tradeoff" hypothesis [ 21 Cressler]. This states that the benefits of increased replication (and the subsequent increased shedding of virions) must be balanced against the reduction of time during which shedding takes place, and the reduced mobility of hosts. Note that in human diseases such as COVID-19 reduced mobility is likely to have greater impact than increased mortality because even in a severe epidemic such as COVID-19, most deaths occur after the period when transmission is most likely. (Note also that more virulent pathogens may be strongly selected in settings such as hospitals, where transmission can take place even when individuals are very sick if adequate measures not taken to prevent infection.) The trade-off hypothesis was first introduced to help explain patterns in myxomatosis data [ 21 Cressler]. Myxomatosis has been studied intensely because it provides a classic reference for the rapid evolution of virulence. It is a highly pathogenic viral disease, normally spread by mosquitos, that jumped from New World rabbits to European rabbits. During the first year after its introduction to Australia, it is estimated to have killed $99.5 \%$ of the rabbits that it infected [ 22 Fenner]. Clearly though, even this high rate allowed around $0.5 \%$ to recover and breed and within "a few years" the genetic resistance to the disease was seen to increase in an area where there were annual severe outbreaks of the disease. However, independent testing with laboratory rabbits showed that milder viral strains emerged on a shorter time-scale. For example, a virulent (grade I) strain was introduced to rabbits at Lake Urana in 1952, causing an outbreak with a case-mortality rate of over $99.5 \%$ [ 22 Fenner]. Eleven months after the first outbreak ended, a new outbreak occurred that was caused entirely by attenuated strains of grade III severity. It was suggested that the over-all trend towards moderate virulence (grade III) can be explained by the selective advantage for mosquito transmission of strains which cause extensive and long-persisting infectious skin lesions in rabbits [22 Fenner]. Interestingly, when very mild strains (grade IV) were introduced in other locations they often evolved increased virulence, and grade III strains were later recovered. This review suggests that similar selective trends can act on respiratory viruses, such that strains with intermediate pathogenicity can become established.

There is other evidence for the moderation of virulence in viral infections. If natural selection tends to reduce the severity of the most pathogenic illnesses such that the period of transmission can increase, there should be differences between illnesses that are transmitted by insects (or other vectors) compared to those that are transmitted by direct contact. This is because transmission via vectors can take place whether or not the host is immobilized, whereas direct contact between individuals will be reduced by immobilization. Ewald, who introduced an early version of the tradeoff hypothesis in 1983, showed that pathogens that are transmitted without vectors are significantly more likely to cause illnesses that have mortality below $1 \%$ than those transmitted by vectors $(\mathrm{P}<$ 0.0005) [23 Ewald]. 


\section{Dormancy in respiratory viruses.}

Galanti et al. performed the first large-scale community study across multiple age groups to assess the prevalence and pathogenicity of 18 common respiratory viruses in New York City from the fall of 2016 to the spring of 2018 [24 Galanti]. The results were remarkable: on average, only $30 \%$ of detectable respiratory infections were symptomatic. Influenza and metapneumovirus were most pathogenic, with roughly $50 \%$ and $70 \%$ of cases being symptomatic respectively. A longitudinal analysis of the same data found that roughly as many individuals were carrying respiratory viruses in summer as in winter [ 25 Galanti]. Other studies have detected a variety of viruses in asymptomatic individuals. For example, Granados et al. showed that asymptomatic rhinovirus activity preceded peak symptomatic activity in September and October and was associated with lower viral load [25b Granados]. Other studies identified asymptomatic individuals who had not seroconverted, but who were shedding influenza A [25c Tandale, 25d Papenburg, 25e Thai] and influenza B [25f Foy]. Thai et al. commented that this "may indicate that viral RNA remained in the respiratory tract without being internalized and eliciting an immune response" [25e].

Studies of respiratory viruses in Antarctica are easy to interpret because infections are rare after the first month of isolation. Such studies lead to similar conclusions. For example, after 12 months of complete isolation a geologist at the Mawson station picked up a respiratory virus from a visiting field party [26 Cameron]. He experienced no symptoms for 17 days, at which time he and three colleagues developed muscle aches and sore throats after being exposed to cold and damp conditions. Another study at Adelaide Island in 1969 found that after 17 weeks of complete isolation several men developed colds four days after the air temperature fell in one day from $0^{\circ} \mathrm{C}$ to $-24^{\circ} \mathrm{C}$ [27 Allen]. Muchmore et al. reported parainfluenza shedding by healthy young adults throughout the $81 \frac{1}{2}$-month winter isolation period at Amundsen-Scott South Pole Station during 1978, with two episodes of respiratory illness caused by parainfluenza after 10 and 29 weeks [ 28 Muchmore]. These studies show that respiratory viruses can become dormant, and suggest that they can be activated by low temperatures and host chilling, giving rise to respiratory illness.

SARS-CoV-2 is estimated to cause completely asymptomatic infections in $17 \%$ of cases [ 29 Byambasuren]. Asymptomatic individuals were found to be $42 \%$ less likely to transmit the virus than symptomatic individuals. It is striking that COVID-19 rates increased more rapidly in countries in the Southern Hemisphere during the winter months (June - August 2020) in comparison to countries in the Northern Hemisphere which experienced a decrease during the same period (which comprised their summer months). These observations suggest that despite being a recent "spill-over" to the human' species, SARS-CoV-2 has retained or gained significant thermal sensitivity. It is also striking that COVID-19 illness increased very quickly in many countries in the Northern Hemisphere when temperatures dropped at the end of summer. TD-VT suggests that these rapid increases were at least partly driven by asymptomatic cases being converted to symptomatic by the activation of dormant SARS-CoV-2 virions by lower temperatures.

\section{The explosive arrival and abrupt termination of influenza epidemics}

The pattern of dormancy followed by low-temperature-activation may explain the explosive arrival and abrupt termination of influenza epidemics recorded by Hope-Simpson and others (Figure 9). TDVT suggests that a virus such as influenza can enter a community either without symptoms or with only minor cold symptoms. If the temperature subsequently drops, feverish infections are triggered by the activation of dormant viruses. If the temperature then remains stable no further severe infections develop and the epidemic may end abruptly when the first batch of feverish illnesses are resolved. The TD-VT hypothesis can therefore explain these observations of influenza epidemics, which are otherwise problematic. 


\section{Biochemical evidence that many respiratory viruses are thermally-}

\section{sensitive}

Andre Lwoff proposed in 1959 that the degree of virulence of viruses is related to their level of thermal sensitivity, i.e. greater sensitivity to heat is correlated with reduced virulence [Lwoff]. Richman and Murphy confirmed this association in 1979, suggesting that $t$ mutations were themselves responsible for this attenuation. They pointed out that many naturally-occurring viruses were $t s$, and noted that $t s$ influenza, RSV, parainfluenza, and foot-and-mouth consistently replicated more rapidly in the nasal cavities of a variety of animals than in their lungs [6 Richman].

Most laboratory strains of respiratory viruses are propagated in cell cultures at around $37^{\circ} \mathrm{C}$, which may result in the rapid loss of $t s$ characters, especially since viruses often mutate very rapidly when they are introduced to new hosts. For example, a $21^{\text {st }}$ Century study, which looked at the effect of temperature on the replication in mammalian cells of H1N1, H1N2 and H3N2 influenza A viruses isolated from pigs and birds, found that only 3 of 7 strains examined consistently replicated faster at $37^{\circ} \mathrm{C}$ than $40^{\circ} \mathrm{C}$. Note, however, that (1) the viral strains studied had been sampled up to 23 years before the publication, and propagated in eggs and cell cultures at unknown temperatures in the meantime; and, (2) all strains were "amplified" at 36-37C in embryonated chicken eggs for up to four days, prior to examining thermal sensitivity. This procedure might well have selected mutated sub-strains that lacked thermal sensitivity. This has in fact been seen in earlier studies - the $t s$ character of strains was lost in conditions that allowed rapid replication. Chu et al. passaged a naturally-occurring ts subclone of the influenza A H3N2 strain Ningxia/11/72 [52 Chu] three times through chicken embryos at a low temperature $\left(33^{\circ} \mathrm{C}\right)$, and were surprised to find that a non-ts strain was produced. Similarly, Oxford et al. [34 Oxford] found that when a naturally-occurring ts virus, $A / E n g / 116 / 78$ (H1N1), was passaged five times through chicken eggs at low temperature $\left(33^{\circ} \mathrm{C}\right)$ it progressively lost its $t s$ character. Both groups concluded that even at the permissive temperature $\left(33^{\circ} \mathrm{C}\right)$ the ts phenotype may confer a selective disadvantage in eggs because eggs allow rapid replication of influenza virions.

In spite of practical difficulties in carrying out experiments, and a lack of awareness of the natural thermal sensitivity of many respiratory viruses among microbiologists, viral thermal sensitivity has been seen in the wet-lab on many occasions.

It is often easier to propagate respiratory viruses that are freshly collected from patients by incubation at temperatures below $37^{\circ} \mathrm{C}$. Rhinoviruses were first isolated at $35^{\circ} \mathrm{C}$ but a greater variety of rhinoviruses was discovered at $33^{\circ} \mathrm{C}[30 \mathrm{Tyrrel}]$. Coronaviruses were first isolated at $33^{\circ} \mathrm{C}[31$ Bradbourne]. In 1962 Stern and Tippett [32] found that four viral specimens from patients with $\mathrm{H} 2 \mathrm{~N} 2$ "Asian" influenza grew in eggs at $33^{\circ} \mathrm{C}$ but not at $37^{\circ} \mathrm{C}$. They also grew in monkey cells at $33^{\circ} \mathrm{C}$ but more slowly or not at all at $37^{\circ} \mathrm{C}$. The authors also found (in 1962) that the well-known FM1 (H1N1, 1947) and PR8 (old-style HON1, 1934) strains both grew more slowly in monkey cells at $37^{\circ} \mathrm{C}$ than at $33^{\circ} \mathrm{C}$. In 1977 , Kung et al. found that nine of ten isolates of the newly emerged "Russian" $\mathrm{H} 1 \mathrm{~N} 1$ influenza were ts [33 Kung]. Oxford et al. found that 17 of 26 recent H1N1 isolates, and 2 of 11 recent $\mathrm{H} 3 \mathrm{~N} 2$ isolates were $t s$, giving at least 10 times more viral plaques after incubation at $34^{\circ} \mathrm{C}$ compared to $38.5^{\circ} \mathrm{C}$ [34 Oxford]. Jardon and Garnier found a 3-fold increase in recombinant adenovirus yield in HEK293S cells at $35^{\circ} \mathrm{C}$ compared to $37^{\circ} \mathrm{C}$ [35 Jardon]. Sato et al. recommended $34^{\circ} \mathrm{C}$ to grow parainfluenza virus in a melanoma cell line, MNT-1 [36 Sato]. A more recent study by the same authors, and others, found that the same cell-line was suitable for the growth of human metapneumovirus, and they recommended $33^{\circ} \mathrm{C}$ for this purpose [37 Sato].

In many cases, particular steps in the life-cycle of respiratory viruses were found to be ts. Russell saw an "unexpected result" when he measured the uptake of the triple reassortant influenza virus $\mathrm{A} / \mathrm{Jap} / \mathrm{Bel}$ into cells [ 38 Russell]: $100 \%$ of the virus entered cells at $30^{\circ} \mathrm{C}$, compared to $50 \%$ at $38^{\circ} \mathrm{C}$ (Figure 10). Takashita et al. found roughly twice the amount of the hemagglutinin-esterase-fusion protein of influenza $\mathrm{C}$ on the cell surface at $33^{\circ} \mathrm{C}$ compared to $37^{\circ} \mathrm{C}$, and membrane fusion mediated 
by HEF was observed at $33^{\circ} \mathrm{C}$ but not at $37^{\circ} \mathrm{C}$ [ 39 Takashita]. This was due to instability of the trimeric form of $\mathrm{HEF}$ at $37^{\circ} \mathrm{C}$. Plotch and Krug [40] reported that the greatest activity of the RNA polymerase of WSN virus was at $30-32^{\circ} \mathrm{C}$. This is similar to the optimum temperature of the polymerase of influenza C, which is $33^{\circ} \mathrm{C}$ [ 41 Nagel, 42 Muraki]. Ulmanen et al. [43] found that the rate of transcription by detergent-treated influenza $A$ viruses was about 10 times greater at $33^{\circ} \mathrm{C}$ than at $39.5^{\circ} \mathrm{C}$, and that the binding of a cleaved primer cap to the viral cores was "unexpectedly" much weaker at $39.5^{\circ} \mathrm{C}$ than at $33^{\circ} \mathrm{C}$. Scholtissek and Rott [44] showed that the optimum for the polymerase of the Rostock strain of fowl plague virus was five degrees below chickens' normal body temperature $\left(41^{\circ} \mathrm{C}\right)$. Several reports showed that temperature affects the balance between transcription and viral replication. Kashiwagi et al. [45] found that, for five varied influenza A strains, vRNA unexpectedly decreased when the temperature was increased from $37^{\circ} \mathrm{C}$ to $42^{\circ} \mathrm{C}$. The PA subunit of the viral polymerase caused this thermal sensitivity. Dalton et al. suggested that the "switch" that regulates the transition from transcription to replication is dependent on temperature. They showed that the production of mRNA by the PR8 influenza strain is favored at a higher temperature $\left(41^{\circ} \mathrm{C}\right)$, with very little vRNA being produced at that temperature [46 Dalton]. A plasmid-based recombinant system used by the same authors showed that as the incubation temperature increased from $31^{\circ} \mathrm{C}$ to $39^{\circ} \mathrm{C}$ the amount of replicative RNA products (cRNA and VRNA) decreased and a greater accumulation of mRNA was observed. The cRNA formed a complex with the polymerase that was particularly heat-labile.

I noted above that the ts character of strains may be lost in conditions that allow rapid replication. Remarkably, the converse trend has also been seen: conditions that favor the replication of milder strains have produced ts strains. In an interesting review from 1975 [47], Preble and Youngner noted that $t s$ strains often appear spontaneously in persistent infections of cell cultures with a variety of unrelated insect-transmitted and respiratory viruses, including Newcastle disease virus, Western equine encephalitis virus, Sendai virus, measles virus, vesicular stomatitis virus, and Sindbis virus. Persistent infections of cell-cultures with mumps virus and vesicular stomatitis virus were also frequently established by $t s$ virus. Three more recent reports described the establishment of persistent infections of cell cultures by spontaneously-generated ts strains of influenza A [48 Frielle, 49 Liu, 50 Hope-Simpson]. Preble and Youngner pointed out that a balance between viral and cell replication is required to establish persistent infections and that since $t s$ strains tend to be less virulent they may allow such infections to become established [47 Preble]. They suggested that similar mechanisms may be involved in the establishment of persistent infections in animals, such as foot-and-mouth disease. Foot-and-mouth viruses recovered from carrier animals are frequently $t s$, whereas the replication of isolates from animals with acute infections are generally not affected by temperature [51 Gebauer].

Microbiologists tend to focus on mutations that change the sequences of viral proteins. However, RNA secondary structure is inherently ts, and I suggest that conserved RNA structures (such as, in SARS-CoV-2, the s2m structure, the 3' UTR pseudoknot, and the coronavirus packaging signal) may comprise "RNA thermometers" [53 Narberhaus] and so contribute to the evident thermal sensitivity of viruses. Apparently "silent" mutations that affect RNA secondary structure may therefore have profound effects on the pathogenicity of respiratory viruses [54 Chursov] including SARS-CoV-2.

\section{Rashes, chilblains and "COVID toes"}

TD-VT suggests that most respiratory viruses are $t$ and predicts that they will replicate more freely in the nose and throat, because those are usually some of the coldest parts of the body. If respiratory viruses enter the bloodstream, however, TD-VT predicts that they may settle and can replicate in other cold parts of the body such as the skin, especially of the fingers and toes. Virulent human influenza strains occasionally cause rashes. For example, three children who were infected with pandemic H1N1 influenza in 2009 ("swine flu") presented with petechial rashes [55 ShachorMeyouhas]. Chilblains are normally considered to be an inflammatory skin condition related to an abnormal vascular response to the cold. They typically present as tender red or bluish lesions 
located on the dorsal aspect of the fingers, toes, ears and nose [56 Vano-Galvan]. TD-VT suggests that at least some chilblains are caused by the replication of virus in the extremities and this has not been ruled out. COVID-19 is associated with chilblain-like symptoms referred to as "COVID toes" that mainly occur in older children and adolescents (Figure 11), although it has not been shown that they are caused by the presence of the virus in the feet. Figure 11 shows plaque-like blemishes of different sizes on the feet of a 15-year-old boy that may represent the sites where individual viruses established replication. COVID-19 also causes a variety of skin rashes and blisters [57 Massey].

\section{The adaptation of respiratory viruses to their local climate and}

\section{season.}

Any description of the epidemiology of respiratory viruses needs to explain two further observations: (1) roughly the same set of viruses cause respiratory illness all over the world (Table 2), including tropical and temperate locations, yet ambient temperature in those locations varies greatly; and (2) in temperate locations there is, frequently, a sudden epidemic of colds and flu in the autumn, despite ambient temperatures being similar to those in the same locations in spring, when levels of colds and flu were lower. See Figure 2 for several examples of early autumn respiratory epidemics.

These observations are compatible with the suggestion that selective pressures can adjust the thermal sensitivity of respiratory viruses within a few months. Since too high pathogenicity may reduce viral transmission (as patients become bed-ridden), natural selection may adjust thermal sensitivity to a level that is appropriate to the virus's location, season and climate.

Figure 12 shows that influenza strains move freely around the world. TD-VT says that respiratory viruses adapt to their local ambient temperature so we can expect them to spread throughout the world over time and establish reasonably stable equilibria in all locations (albeit disturbed by seasonal temperature fluctuations in temperate locations). Note however that Figure 12 shows that influenza is more likely to move from hotter to colder locations than in the opposite direction. This is predicted by TD-VT because tropical strains need to be less ts to replicate in nose and throat at higher temperatures, and they are therefore intrinsically more virulent and expected to cause more serious illness if they are transported to temperate locations. Note also that the same virus might colonize locations nearer the (cooler) nose in the Tropics, and nearer the (warmer) lungs in cold locations.

The autumn surge of respiratory illness can be explained by TD-VT if we assume that viruses with the appropriate level of thermal sensitivity are selected in different locations within a few months. During the hotter weather of summer, viral strains with reduced thermal sensitivity are likely to be selected because only less-sensitive strains are active at higher temperatures and able to replicate and be transmitted. When ambient temperature falls in autumn, the temperature in the nose and throat also falls and the respiratory viruses that are already present may suddenly become more active, causing illness.

In winter, on the other hand, the most virulent strains immobilize their hosts, so the more ts (therefore less virulent) strains are most likely to be transmitted. When ambient temperature rises in the spring, these more $t s$ viruses become less active and the number of colds is reduced (according to TD-VT).

The net result is more colds and flu in winter, fewer in summer, with a surge in autumn.

Figure 13 shows these trends schematically.

\section{Chilling of individuals - experimental and observational studies}

Numerous studies from the 1950s and 1960s, including three influential studies by Andrewes, Dowling and Douglas $[58,59,60]$, have been widely interpreted as showing that chilling does not 
increase the chance that individuals will get a cold. These studies were performed with volunteers who were inoculated nasally with suspensions of recycled cold viruses that were taken from previous volunteers. The authors called these "pedigree" strains. (The viral species involved was often unknown.) When individuals were inoculated and then subsequently chilled, the studies found that they were no more likely to get colds than individuals who were not chilled, leading the authors to conclude that chilling does not bring on colds. However, these experiments were designed to be carried out within a limited time-frame, often one week, and infections had to appear quickly if they were to be recorded. It has been suggested that fast-acting viral strains were selected by this procedure that had lost their natural thermal sensitivity at the point of binding or entry into cells [3 Shaw Stewart]. It is therefore possible that chilling increases the risk of getting a cold caused by a "wild" virus, but not a cold caused by a virus such as was used in these studies.

On the other hand, these studies do suggest that human immune defenses are not made meaningfully weaker by chilling, which is evidence against E3 as driver of seasonality.

An interesting study from 1997 by the Eurowinter Group applied the techniques of market research to find correlations between multiple cold-exposure factors and death from respiratory illness in seven regions of Europe, ranging from Northern Finland to Athens (Greece) [61 Donaldson]. The study found that factors that increased personal chilling such as standing still outside for more than two minutes $(p=0.04)$, wearing a skirt $(p=0.005)$, and shivering outside $(p=0.001)$ were significantly correlated with increased risk of death from respiratory illness (Figure 14). On the other hand, factors that reduced personal chilling such as wearing a hat outside $(p=0.004)$, wearing an anorak outside ( $p=0.001)$ and outdoor exercise sufficient to cause sweating $(p=0.02)$ were significantly correlated with reduced risk of death from respiratory illness.

The observation that outdoor exercise that causes sweating seems to be protective is interesting. This seems to require explanation by a combination of TD-VT and E3 (the explanation that says that personal chilling reduces our immunity). TD-VT says that breathing cold air will "wake up" dormant virions, while the lack of chilling (implicit in the stipulation of sweating) may ensure that the activated virions - presumably now visible to the immune system - can be destroyed by our defenses. Note that the Eurowinter Group found that frequency of going out was only slightly correlated with reduced mortality, suggesting that this apparent protective effect is not mainly (or only) driven by the regular elimination of activated virions in small batches.

\section{Practical recommendations suggested by TD-VT for avoiding and treating respiratory illnesses}

\section{The TD-VT hypothesis makes to following suggestions for avoiding respiratory illness}

1. Dress warmly to avoid chilling [61 Donaldson]. The body rapidly reduces the blood flow to the respiratory tract during chilling, reducing the temperature of the lining of the respiratory tract [62 Mudd]. TD-VT says chilling will cause dormant respiratory virions to become active and begin to replicate.

2. Avoid standing still outdoors in cold temperatures [61 Donaldson].

3. Take regular outdoor exercise sufficient to cause sweating [61 Donaldson]. The reason that this is correlated with a reduced chance of dying from respiratory illness is unknown, but it seems likely that breathing cold air activates dormant virions, while dressing warmly improves immune defenses in the respiratory tract [3 Shaw Stewart]. Exercise and fast breathing reduce the temperature of the respiratory tract. Performing exercise regularly, without chilling, may therefore allow respiratory virions to be eliminated in small batches.

Suggestions from TD-VT for treating existing respiratory illness.

1. Keep the temperature of the patient absolutely constant and warm. 
2. Do not take exercise when symptoms begin. The respiratory symptoms indicate that the immune system is already actively removing viruses from the respiratory tract. Rapid breathing cools the respiratory tract and it would be unhelpful to increase the load by activating more virions.

3. Keep the air in the sick-room warm to increase the blood flow to the respiratory tract [62 Mudd].

4. Avoid chilled drinks and ice-cream etc. to avoid cooling the throat.

5. Avoid hot drinks. Some steps in the life-cycle of influenza and possibly other respiratory viruses are activated by higher temperatures. For example, several studies showed that the production of influenza viral proteins increased at temperatures above the normal temperature of the respiratory tract [43 Ulmanen, 45 Kashiwagi, 46 Dalton].

\section{Experimental testing of TD-VT}

The TD-VT hypothesis is testable at many levels, and suggestions for experimental testing have already been made [3 Shaw Stewart]. Important suggestions to test the hypothesis include: investigating the best temperatures for growing newly-isolated respiratory viruses in tissue cultures; infecting animals with labelled respiratory viruses, and determining the positions of replicating viruses in the respiratory tracts of animals that have experienced different temperature regimes (such as temperature step-up and step-down sequences); following viral entry, transcription, splicing, translation, genomic replication, assembly and release of daughter virions from cells in temperature step-up and step-down experiments (Figure 3); investigating of the effect of mutations on temperature-sensitivity, including effects on RNA secondary structure, possibly using DNA-based "recombinant" systems (because DNA sequences are much more stable than the RNA sequences of replicating viruses); randomized controlled studies to test the suggestions in the section immediately above for avoiding and treating respiratory illnesses; and randomized controlled studies where healthy individuals are chilled to see if this results in increased respiratory illness arising from the "wild" respiratory viruses that they happen to be carrying at the time of the experiment. 
Mainz, Germany, 2000 - 2008 (oceanic climate) du Prel, Clinical Infectious Diseases 49.6 (2009): 861-868.

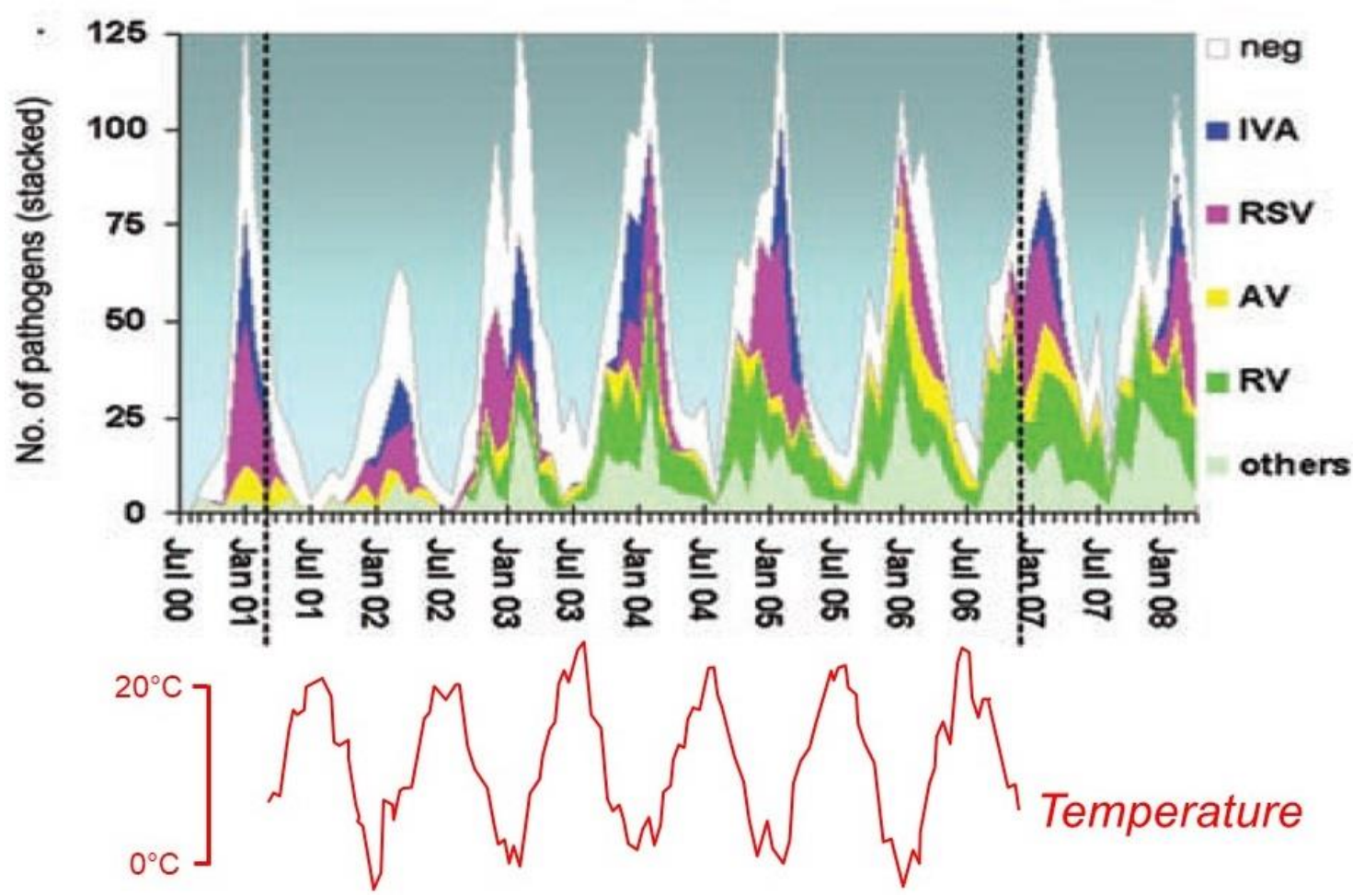

Figure 1: An example of winter seasonality: the viruses that caused respiratory tract infections in hospitalized children in Mainz, Germany, which has an oceanic climate, $2000-2008$. Note that the timing of illness caused by particular viral species is very variable. For example, rhinovirus sometimes arrived early (as in 2004), but sometimes persisted until late in the cold season (as in 2007). Nevertheless, the maximum for all hospitalizations was normally around February, and the minimum around August. Adapted from du Prel JB et al. Clin Infect Dis 2009; 49(6):861-8. 

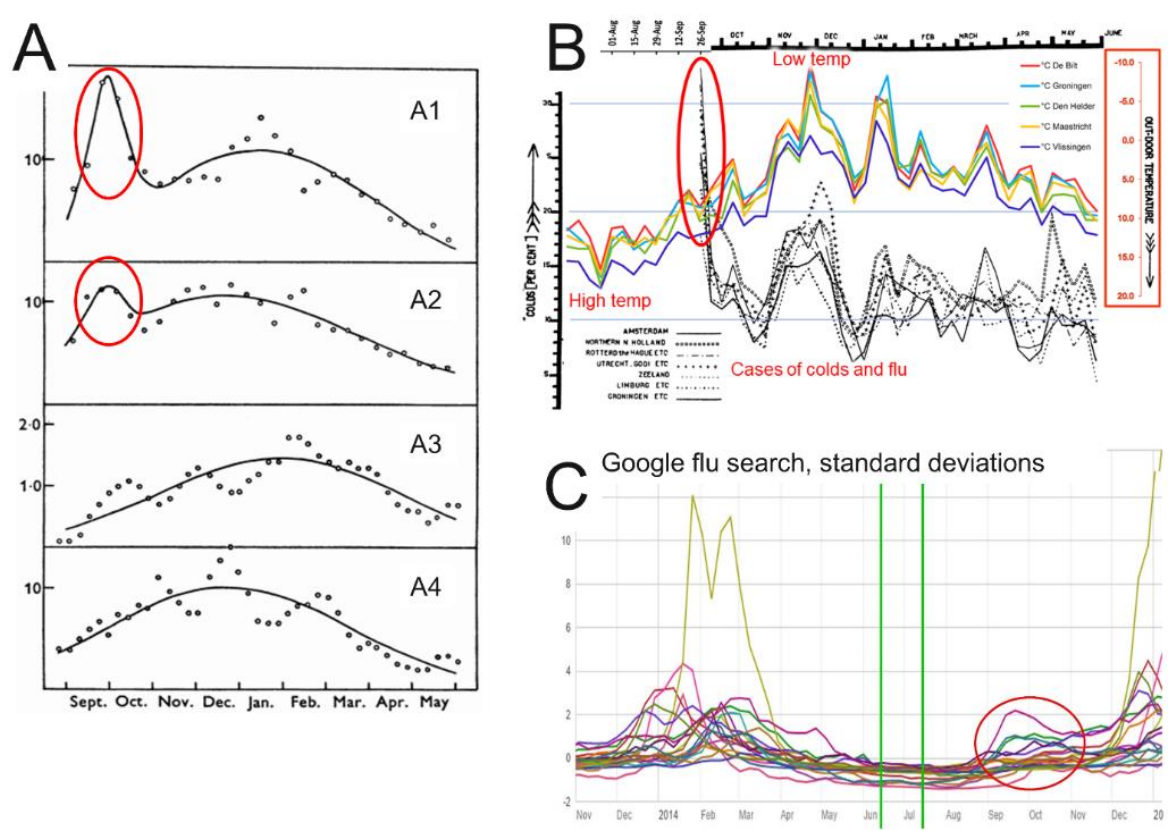

Figure 2: four datasets that show an "autumn surge" in the number of colds (red ovals). (A) Graphs show the average yearly incidence of colds for each period of 10 days $+/-1$ day [10 Lidwell]. A1: London, 1951-1955; A2: Newcastle, 1951-1957; A3: Cirencester, 1954-1956; A4: Chalke valley, 19481949. Note that for London and Newcastle the number of colds at the end of September was greater than or equal to the number in midwinter. For details see the original paper. However, the trend is not universal, and in Cirencester and Chalke valley smaller autumn surges were seen. (B) At the beginning of van Loghem's study in September 1925 one third of respondents in Amsterdam had colds, with high numbers in some other regions (red oval) [9 Van Loghem]. For more information see the legend of Figure 5. (C) In September 2014 Google "flu search" activity increased in most countries in the Northern Hemisphere (red oval). For more information see the legend of Figure 4. Section (A) is adapted from Epidemiology \& Infection, 1965 Sep;63(3):427-39, while section (B) is adapted from Epidemiology \& Infection, 1928 Aug;28(1):33-54. (C) Was retrieved in August 2015.

\section{TDVT}



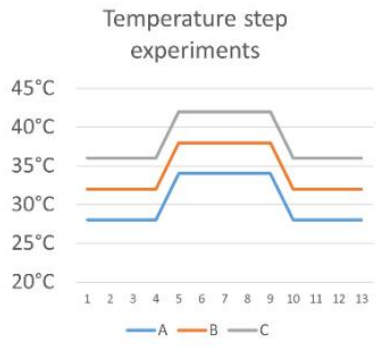

$-\mathrm{A}-\mathrm{B}-\mathrm{C}$

Figure 3: steps in the life-cycle of respiratory viruses that might be temperature sensitive (ts).

Experiments will be needed to determine which steps in the life-cycles of any particular respiratory virus are ts. The diagram shows influenza virus in a cell as an example. All steps, numbered 1-7, might be $t$. Note that the secondary structure of RNA is inherently $t s$, so steps involving RNA are good candidates to be involved in ts responses. Steps 1, 3 and 4 have previously been found to be $t s$ in influenza in the laboratory (see main text for details). The inset at the top right illustrates three temperature step-up and step-down experiments labelled A, B and C (see main text). 


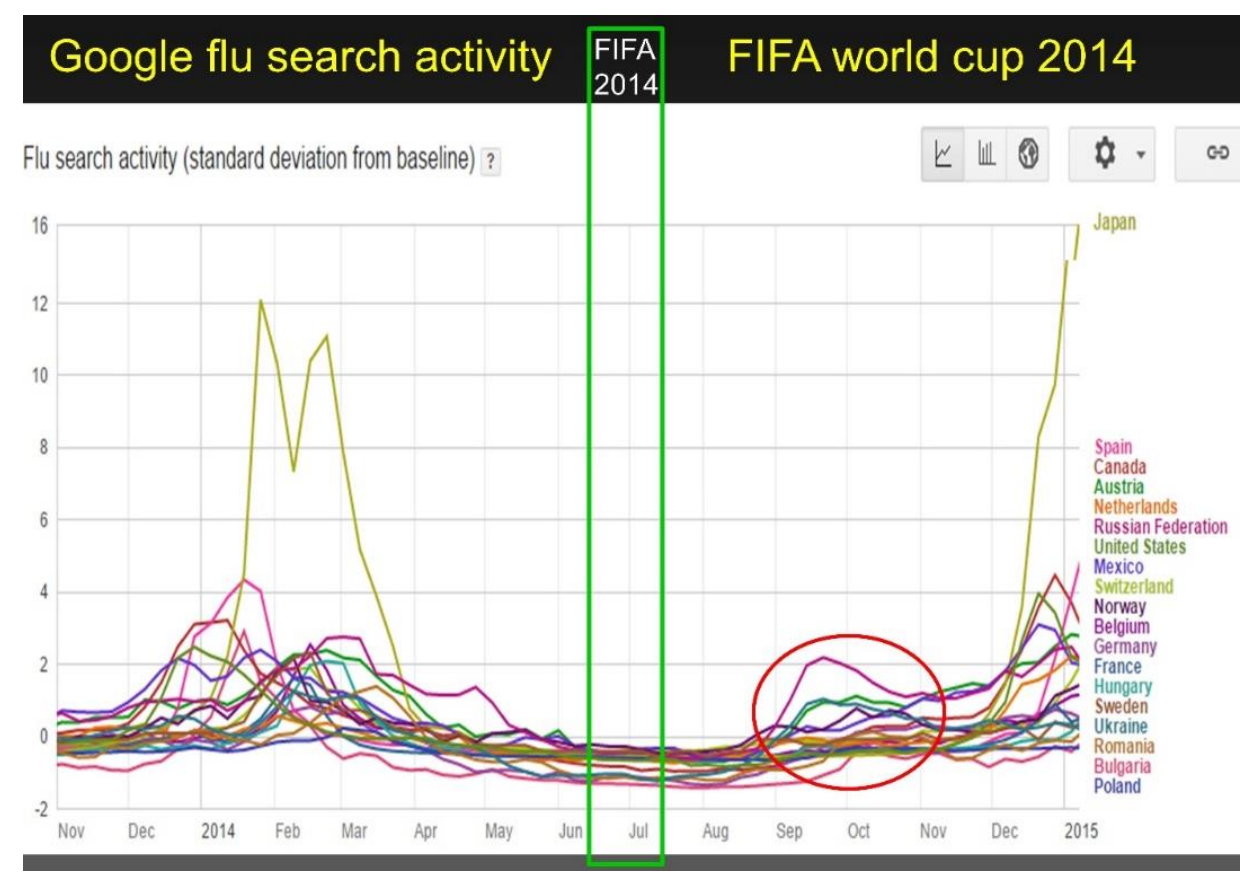

Figure 4: Google "flu search" activity during FIFA 2014. Google flu search measured the number of people who search for terms related to colds and flu using the Google search engine. During major sporting competitions people often crowd together in bars and at home to watch the events. The figure shows that during the 2014 FIFA World Cup, in the 18 countries in the Northern Hemisphere where flu search activity was reported, there was no increase in the number of Google searches for related terms. This suggests that the epidemics that are apparent in winter in every country are not mainly driven by crowding (E1). Notice the epidemics of colds in September 2014 (red oval). Autumn epidemics quite often appear when the temperature dips at the end of summer (Figure 2). 


\section{Netherlands, 1925 - 1926}

Van Loghem, J. J. Epidemiology \& Infectior 28.1 (1928): 33-54.

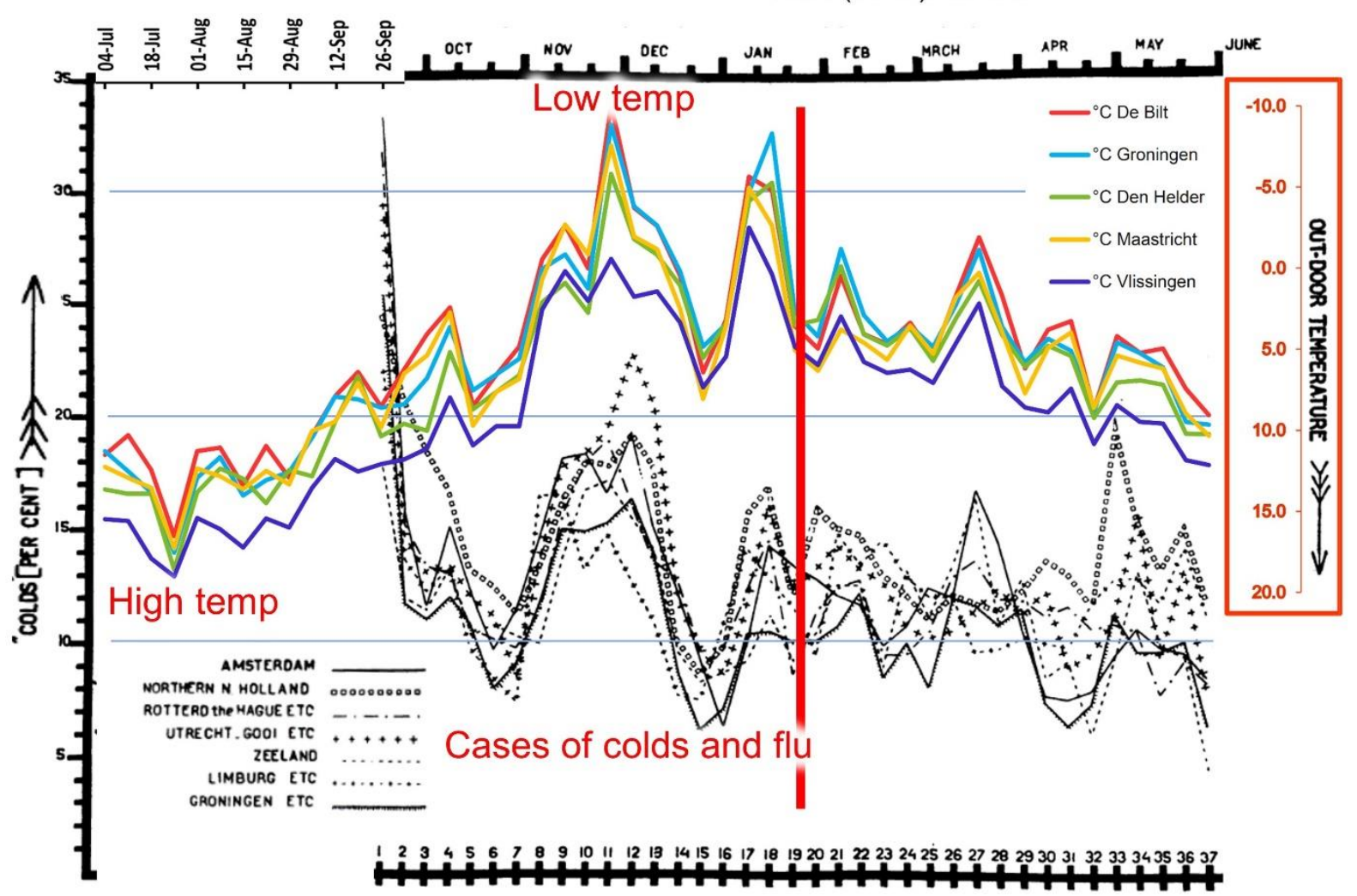

Figure 5: Graph II from van Loghem's report on the epidemiology of respiratory illnesses in the Netherlands in the winter of $1925 / 26$. I have superimposed the ambient temperatures recorded at five Dutch weather stations (colored lines) with the temperature scale inverted (lowest temperatures at the top). Note that (1) by far the highest number of illnesses in the whole study was at the very beginning, in September 1925; (2) there is an extraordinary correlation between ambient temperature, and colds and flu throughout the Netherlands; (3) colds and flu arrived in all areas of the Netherlands almost simultaneously, with illnesses synchronized to within $1-2$ weeks at some points; (4) the correlation is strongest in the first part of the cold season. After the red line the relationship between temperature and colds became less clear. Adapted from the Journal of Hygiene, 28(01), 33-54. 




Figure 6: monthly serum levels of vitamin D in men (dark grey) and women (light grey). Note that (1) vitamin D levels change slowly over several months without major fluctuations that would result from the influence of short-term changes in the weather (although in a few cases the increases and decreases are not monotonic); (2) the highest vitamin D levels were in September, which coincides with the yearly surge in the number of colds that frequently appears during that month (see figure 2). This suggests that vitamin $D$ is not the main driver of viral winter seasonality. This figure was originally published in Am J Clin Nutr 2007, 85: 860- 868. 


\section{Prevalence of influenza \\ NW}
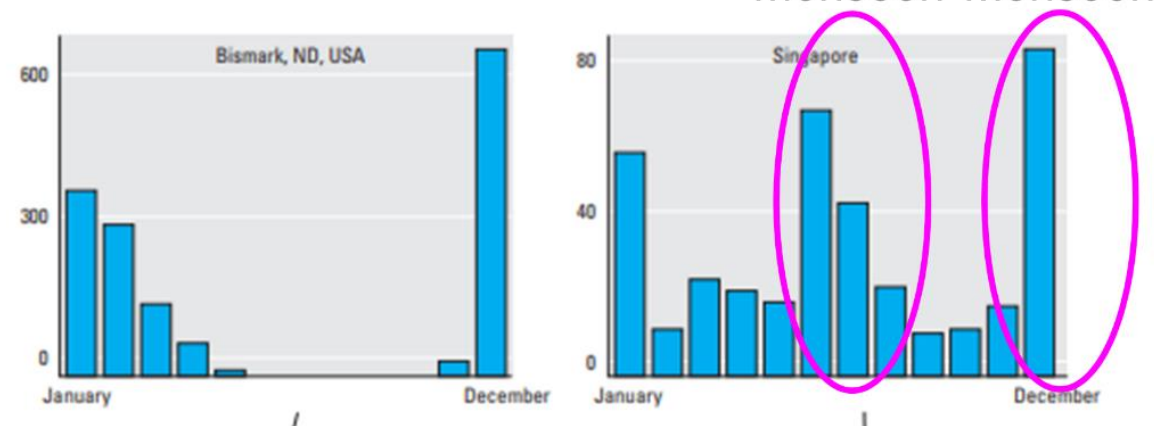

Wind and rain cause personal chilling


chilling

Figure 7: seasonal patterns of influenza in four sites across several latitudes worldwide. In temperate regions epidemics normally occur during the winter months. Seasonal influenza activity in the tropical locations is greatest during the rainy season. The bar charts indicate the average number of detected influenza isolates ( $y$-axis) over several years for Singapore, Fortaleza (Brazil), Bismarck (North Dakota, USA) and Sydney (Australia). Rainfall in Fortaleza and the two monsoons in Singapore are shown in purple. Adapted from Environmental health perspectives, $2011 \mathrm{Apr}$; 119(4):439-45. 

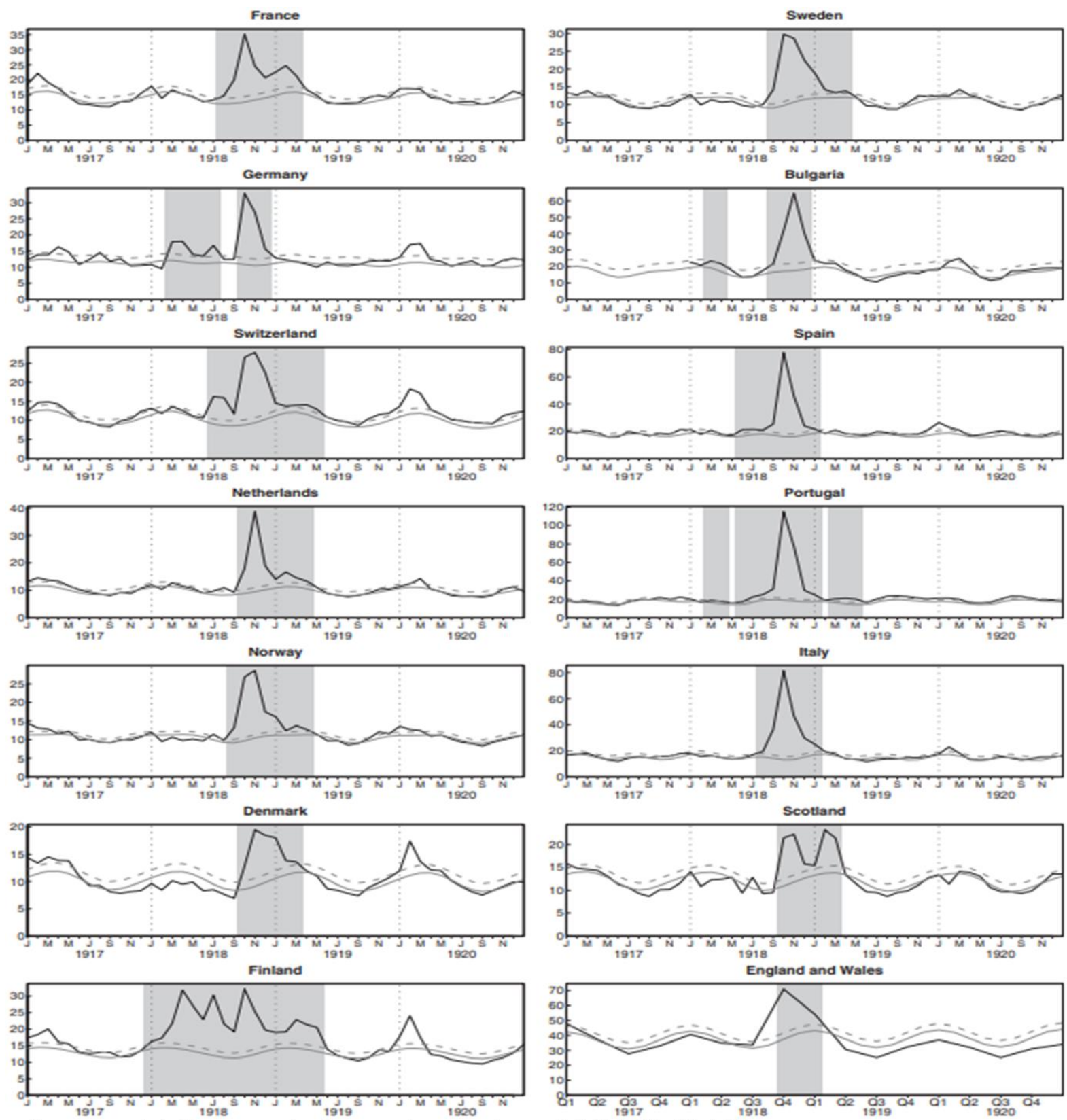

Ansart et al. Influenza and other respiratory viruses 3.3 (2009): 99-106.

Figure 8: mortality rate (black line) in 14 European countries during the Spanish Influenza epidemic, 1917-1920. The continuous grey line shows predicted mortality, the dashed grey line the pandemic threshold (for more information see the original paper) [19 Ansart]. Note that most countries only experienced one main peak, occurring the same two-month period, and that the epidemics seen in the winter of 1919-1920 were much smaller or not apparent. Mortality in Finland is difficult to interpret during and after the Finnish Civil War (January to May 1918). This figure was originally published in Influenza and other respiratory viruses, 2009 May;3(3):99-106. 
The 8 largest influenza outbreaks in Cirencester, UK 1946-74.
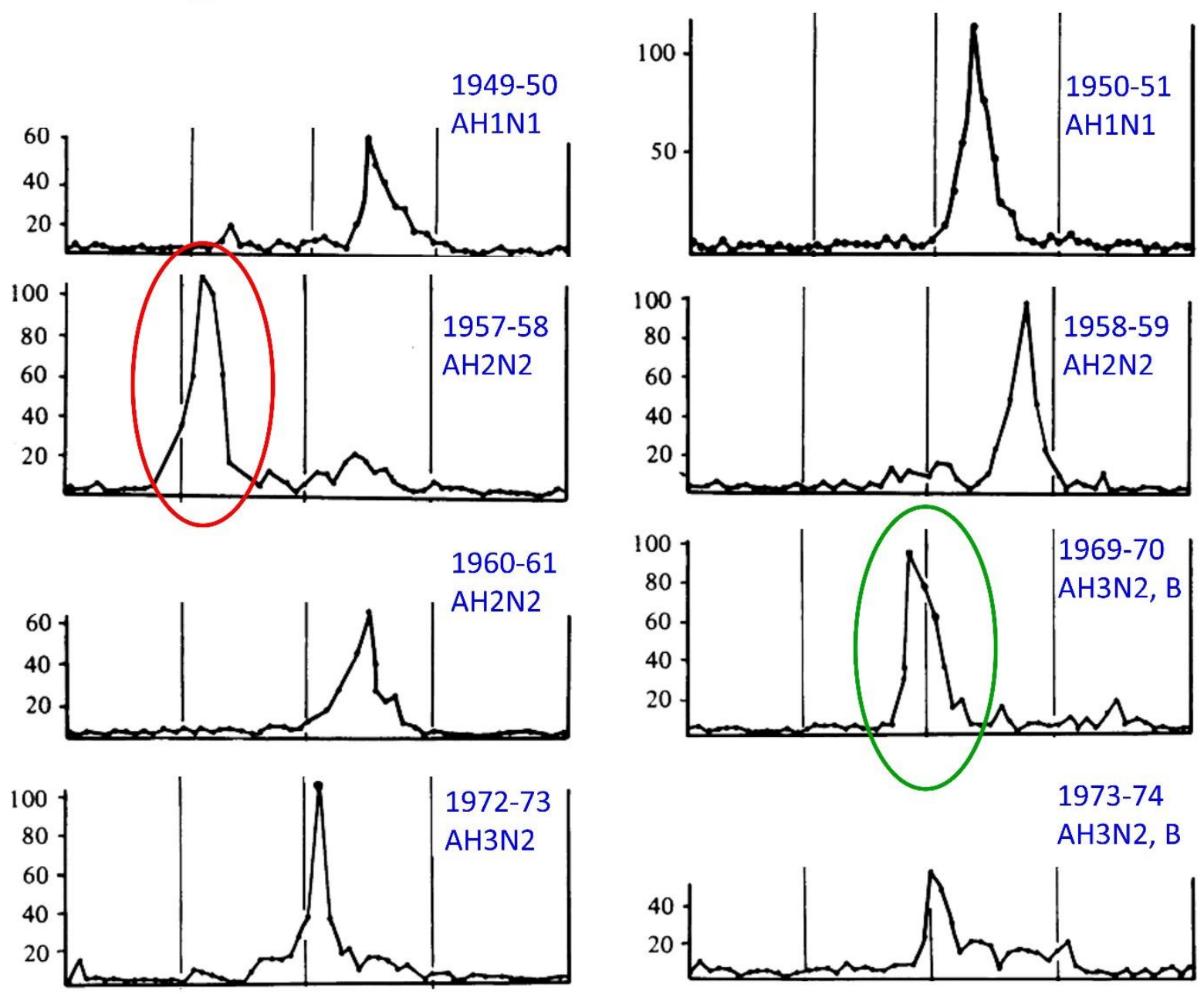

The graphs show the number of patients treated for acute febrile respiratory illness. The red oval shows the arrival of Asian flu, green, the first major epidemic of Hong Kong flu (which arrived the previous year). Data from Hope-Simpson, R.E. Epidemiology \& Infection 86.1 (1981): 35-47.a

Figure 9: the eight largest influenza outbreaks in Cirencester, UK, 1946-1974. See main text for discussion. Adapted from Epidemiology \& Infection, 1981 Feb;86(1):35-47. 


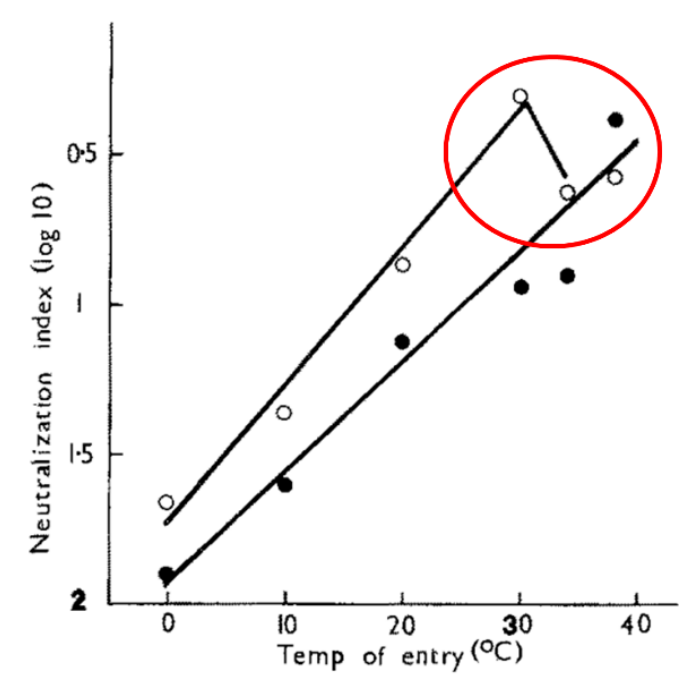

Figure 10: The effect of temperature on influenza virus entry into cells. Influenza virus was preadsorbed to MDBK cells at $0^{\circ} \mathrm{C}$ and then pulsed at varying temperatures of up to $38^{\circ} \mathrm{C}$ for 120 minutes [38 Russell]. Entry into cells was assessed by any escape from subsequent neutralization using a monoclonal antibody to haemagglutinin. Circles show the triple reassortant influenza virus $\mathrm{A} / \mathrm{Jap} / \mathrm{Bel}$, black dots the double reassortant A/NIB-8. Note that, (red oval), at $34^{\circ} \mathrm{C}$ and $38^{\circ} \mathrm{C}$ less $\mathrm{A} / \mathrm{Jap} / \mathrm{Bel}$ escaped neutralization by MAb by entering cells than at $30^{\circ} \mathrm{C}$. This was repeated on two separate occasions using a chicken anti- $\mathrm{H} 2$ serum when 100 per cent of virus escaped neutralization at $30^{\circ} \mathrm{C}$ as compared to 50 per cent at $38^{\circ} \mathrm{C}$ (results not shown). A/NIB-8 entry was not ts and cell entry increased monotonically with temperature. This is one of many reports of unexplained thermal sensitivity of respiratory viruses. Other examples are given in the main text. This figure was originally published in Arch Virol 1986;88(3-4):159-66. 


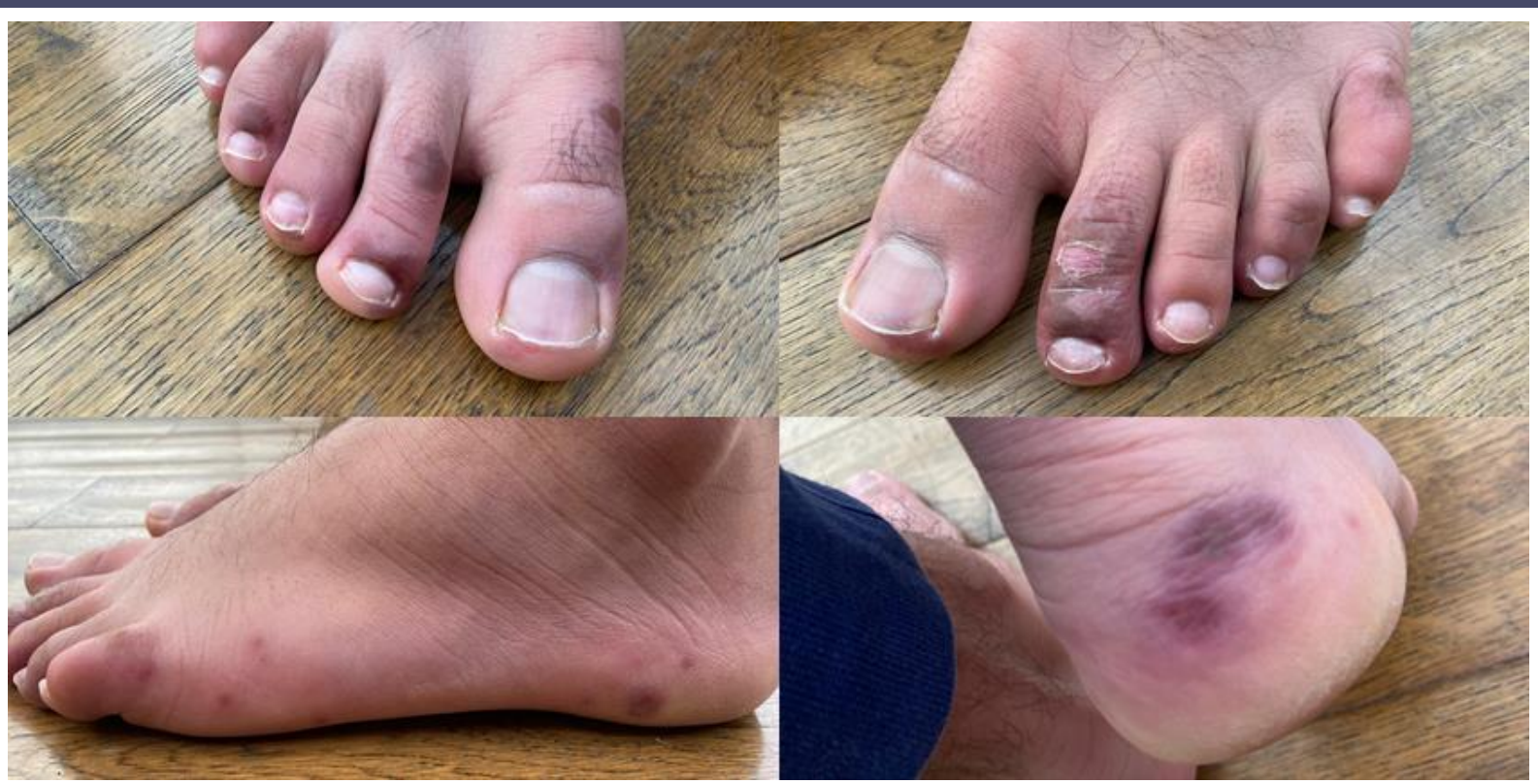

Figure 11: COVID toes, showing discoloration of the feet of a 15-year-old boy, who was in every other respect completely healthy. He usually did his school-work with bare feet. So-called COVID toes are blemishes that sometimes appear on the hands and feet, usually pink or purple, after exposure to SARS-CoV-2. They are most common in older children and adolescents. Note the peeling of dead skin on the second toe, and the plaque-like appearance of blemishes of varying sizes that are scattered around the feet. The TD-VT hypothesis suggests that CoV- 2 virions that may reach the bloodstream are more likely to bind to and invade cells in colder parts of the body, causing these visible symptoms. According to this interpretation each blemish represents a site where a single virus established replication. 


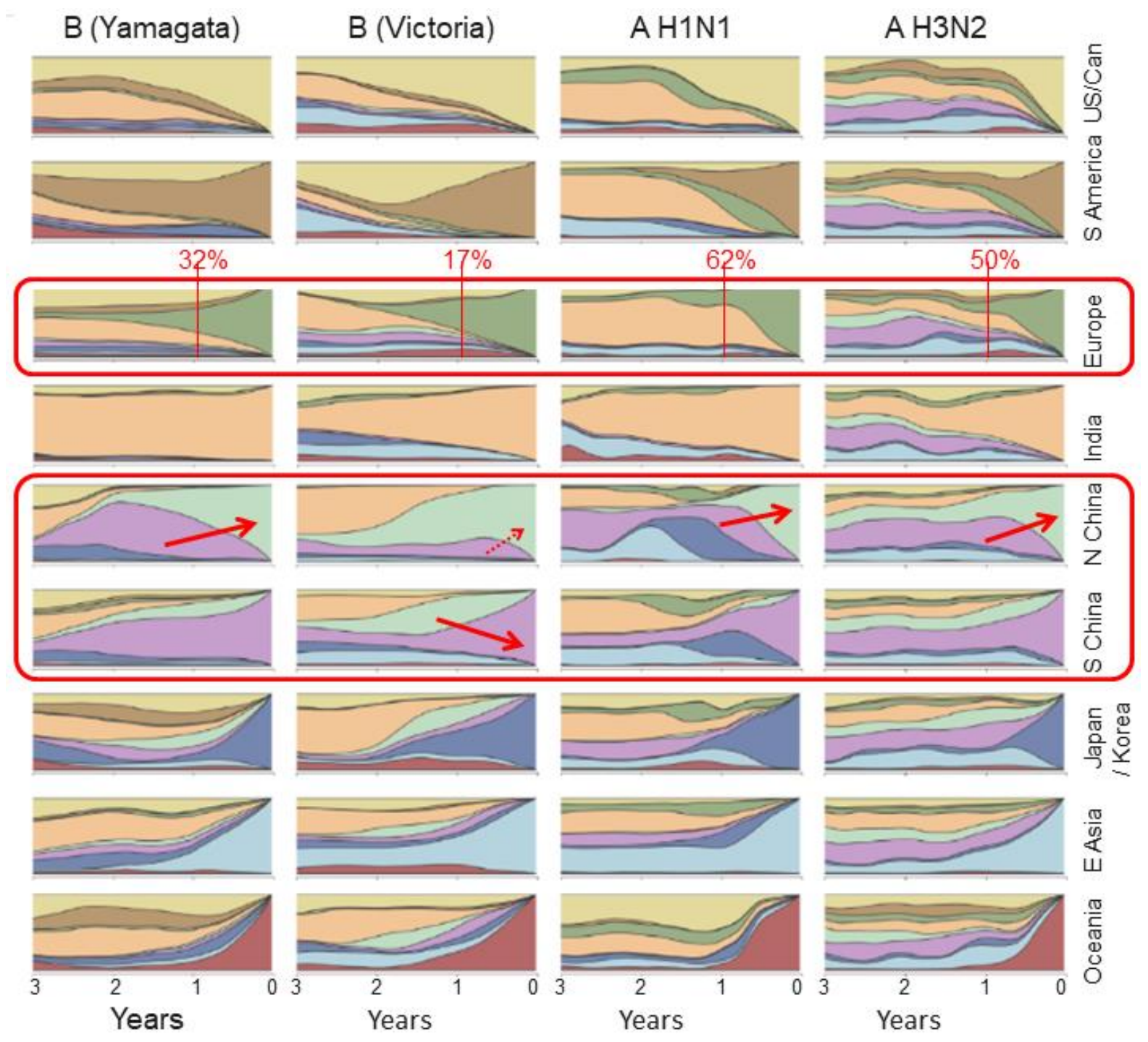

Figure 12: global movement of influenza strains [63 Bedford]. The authors have divided the world into 9 regions, and, by analyzing the sequences of viruses that were sampled worldwide over three years, they charted the movement of influenza strains. The region where each virus was sampled is color coded, and the colors show where the ancestors of current viruses (in each region) came from as you go back in time. The numbers at the bottom show years before arrival of the strain in the region under consideration. The right-hand side of each box is only colored with the region's own color because strains have had no time to move. As you go to the left the colors show where the ancestral viruses were at the time indicated. For example, "Yamagata-like" influenza B viruses in India (fourth row, first column) moved very little during the study, with most viruses at the end being descended from strains that were also in India at earlier times. At the other extreme (bottom right box), almost all H3N2 influenza in Australia had come into the country during the previous year. The figure shows some interesting trends. For example, we can see that influenza tends to move from hotter countries to colder ones. For example, a lot of European strains came from India and other hot countries: 32\% of Yamagata-like B strains, 17\% of Victoria-like B strains, $62 \%$ of H3N2 A strains, and $50 \%$ of H1N1 A strains that were present in Europe at the end of the study came from strains that were in tropical or subtropical regions one year earlier. You can also see that in three out of four cases, more strains move from South China to North China than in the opposite direction (indicated by red arrows). The flow is not in one direction only, however. European and US strains can also make their way to South China and India, although movement in this direction is less frequent. Adapted from Nature, 2015 Jul;523(7559):217-20. 


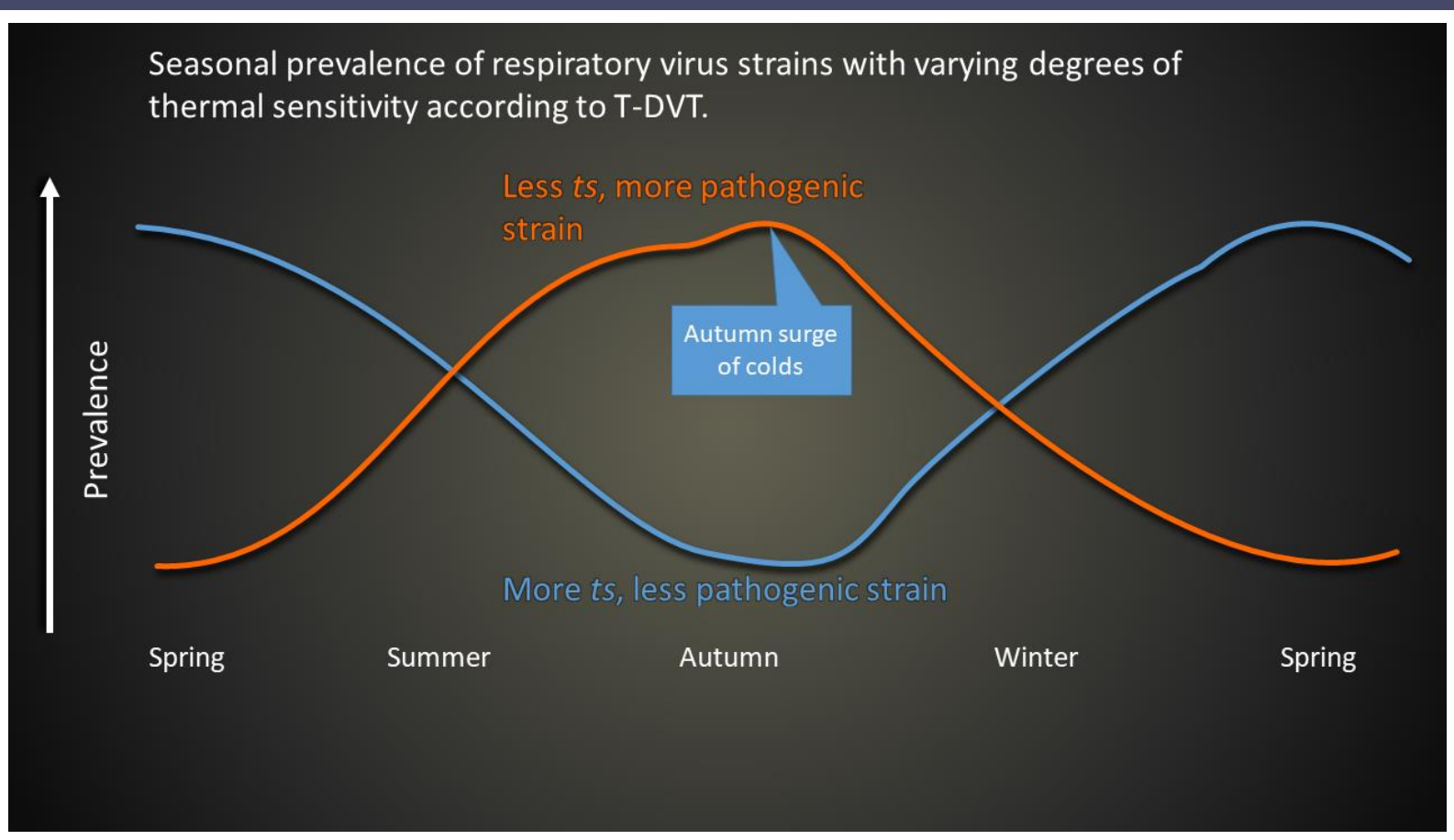

Figure 13. Schematic illustration of the seasonal prevalence of respiratory virus strains with varying degrees of thermal sensitivity, as predicted by the TD-VT hypothesis. Two representative strains are shown, one less ts (therefore more pathogenic) and one more ts (therefore less pathogenic). In reality there would be many strains with varying degrees of thermal sensitivity, and mutations would frequently generate new strains from existing ones with differing thermal properties. During summer the more ts strains replicate very little and become rarer, while more ts strains become more common. In autumn, a surge of colds is often experienced as the less ts strains that have accumulated over the summer are activated by the exposure of hosts to lower ambient temperatures. During winter, both strains can replicate, but the more ts strains increase for a different reason: they are less likely to immobilize their hosts. 
Donaldson, G. (1997). The Eurowinter Group. Lancet, 349, 1341-1346

\begin{tabular}{|l|r|r|}
\hline Cold exposure factor & \multicolumn{1}{|c|}{$\mathbf{R}$} & p-value \\
\hline Mean duration of going out & 0 & 0.922 \\
\hline Living room temperature & -1.8 & 0.001 \\
\hline Frequency of going out & -1.9 & 0.116 \\
\hline Whether going out & -2 & 0.623 \\
\hline Clothing area (fraction of & & \\
body surface) & 2.2 & 0.183 \\
\hline Bedroom heating & -2.8 & 0.053 \\
\hline Long underpants & -3.8 & 0.022 \\
\hline Gloves & -3.9 & 0.065 \\
\hline Long-sleeved vest & -4.5 & 0.072 \\
\hline Hat & -4.7 & 0.004 \\
\hline Long trousers & -6.6 & 0.005 \\
\hline Anorak & -6.7 & 0.001 \\
\hline Overcoat & 7.3 & 0.002 \\
\hline Skirt & 8.3 & 0.005 \\
\hline Sweater & 9.5 & 0.001 \\
\hline Stationery $>2$ mins & 13.2 & 0.04 \\
\hline Sweating outside & -17.5 & 0.02 \\
\hline Shivering outside & 23.8 & 0.001
\end{tabular}

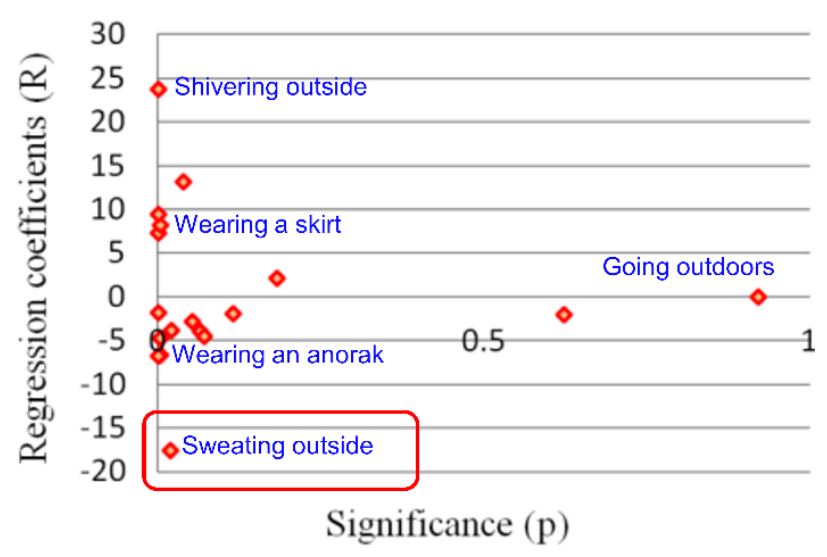

Above: the regression coefficients of mortality due to respiratory disease on 18 personal coldexposure factors, plotted against their significance.

The group used market research techniques to study respiratory illness in 8 European regions, from Northern Finland to Athens.

Figure 14: the regression coefficients (R), and their significance $(p)$, for cause-specific indices of respiratory disease-related mortality on personal cold-exposure factors standardized at $7^{\circ} \mathrm{C}$ mean daily temperature in eight European regions, ranging from northern Finland to Athens [61 Donaldson]. The Eurowinter Group used market research techniques to analyze the climate and the measures taken to protect individuals from low temperatures. Some points are labelled on the plot on the right to illustrate trends. The activities that are most strongly correlated with dying from a respiratory illness are at the top left of the plot, while those that appear to be protective are at the bottom left. Activities that are not correlated with either an increased or decreased chance of dying are on the right or at the middle level. See main text for a discussion of the observation that sweating outside is correlated with lower risk. 


\begin{tabular}{|c|c|c|c|c|}
\hline Family & Genome & $\begin{array}{l}\text { Site of genomic } \\
\text { replication }\end{array}$ & Envelope & Form \\
\hline Adenovirus & Double-stranded DNA & Nucleus & Lacking envelope & Icosahedral \\
\hline $\begin{array}{l}\text { Coronavirus, SARS virus, } \\
\text { COVID-19virus }\end{array}$ & $\begin{array}{l}\text { Positive-sense single- } \\
\text { stranded RNA }\end{array}$ & Cytoplasm & Enveloped & $\begin{array}{l}\text { Spherical with } \\
\text { projections }\end{array}$ \\
\hline $\begin{array}{l}\text { Varicella Zoster Virus } \\
\text { (chickenpox) }\end{array}$ & Double-stranded DNA & Nucleus & Enveloped & Icosahedral \\
\hline Influenza virus & $\begin{array}{l}\text { Negative-sense single- } \\
\text { stranded RNA }\end{array}$ & Nucleus & Enveloped & $\begin{array}{l}\text { Spherical or } \\
\text { filamentous }\end{array}$ \\
\hline $\begin{array}{l}\text { Measles, mumps, } \\
\text { Parainfluenza, respiratory } \\
\text { syncytial viruses, human } \\
\text { metapneumovirus }\end{array}$ & $\begin{array}{l}\text { Negative-sense single- } \\
\text { stranded RNA }\end{array}$ & Cytoplasm & Enveloped & $\begin{array}{l}\text { Spherical or } \\
\text { variable }\end{array}$ \\
\hline Rhinovirus & $\begin{array}{l}\text { Positive-sense single- } \\
\text { stranded RNA }\end{array}$ & Cytoplasm & Lacking envelope & Icosahedral \\
\hline Rubella virus & $\begin{array}{l}\text { Positive-sense single- } \\
\text { stranded RNA }\end{array}$ & Cytoplasm & Enveloped & Icosahedral \\
\hline
\end{tabular}

Table 1: Some characteristics of common respiratory viruses that have winter seasonality.

\begin{tabular}{|l|l|l|l|}
\hline \multicolumn{1}{|c|}{ City } & \multicolumn{1}{|c|}{ Reference } & Climate & \multicolumn{1}{c|}{$\begin{array}{c}\text { Most common respiratory viruses } \\
\text { causing hospitalization of children }\end{array}$} \\
\hline Singapore & $\begin{array}{l}\text { Chew FT et al. Epidemiol Infect } \\
1998 ; 121(01): 121-8 .\end{array}$ & Tropical & RSV, parainfluenza, influenza A, adenovirus \\
$\begin{array}{l}\text { Buenos Aires, } \\
\text { Argentina }\end{array}$ & $\begin{array}{l}\text { Viegas M et al. J Infection 2004; } \\
49(3): 222-8 .\end{array}$ & $\begin{array}{l}\text { Humid } \\
\text { subtropical }\end{array}$ & RSV, influenza A, adenovirus, parainfluenza \\
\hline Mainz, Germany & $\begin{array}{l}\text { Du Prel JB et al. Clin Infect Dis } \\
\text { 2009; 49(6):861-8. }\end{array}$ & Oceanic & Rhinovirus, RSV, influenza A, adenovirus \\
\hline
\end{tabular}

Table 2: the respiratory viruses that most frequently caused hospitalizations of children in temperate and tropical locations. 
E2 - lab studies with viruses in aerosol chambers

\begin{tabular}{|c|c|c|c|c|c|c|}
\hline First author & Year & Reference & Respiratory virus & $\begin{array}{l}\text { Presence of } \\
\text { lipid envelope }\end{array}$ & $\begin{array}{l}\text { Association between } \\
\text { virus survival and } \\
\text { temperature }\end{array}$ & $\begin{array}{l}\text { Association of between } \\
\text { virus survival and } \\
\text { relative humidity }\end{array}$ \\
\hline Harper & 1961 & $\begin{array}{l}\text { J Hyg (Camb). 59: } \\
479-486\end{array}$ & Influenza A & Enveloped & Anticorrelated & Anticorrelated \\
\hline Songer & 1967 & $\begin{array}{l}\text { Appl Microbiol. } 15 \\
\text { (1): } 35-42 .\end{array}$ & $\begin{array}{l}\text { Newcastle disease } \\
\text { virus }\end{array}$ & Enveloped & Anticorrelated & Anticorrelated \\
\hline Songer & 1967 & $\begin{array}{l}\text { Appl Microbiol. } 15 \\
\text { (1): } 35-42 .\end{array}$ & $\begin{array}{l}\text { Infectious bovine } \\
\text { rhinotracheitis }\end{array}$ & Enveloped & & Correlated \\
\hline Akers & 1968 & $\begin{array}{l}\text { Appl Microbiol. } 16 \\
\text { (11): 1811-3 }\end{array}$ & Mengovirus 37A & Non-enveloped & & Correlated \\
\hline Hugh-Jones & 1973 & $\begin{array}{l}\text { J Hyg (Lond). } 71 \\
\text { (2): } 325-39 .\end{array}$ & $\begin{array}{l}\text { Newcastle disease } \\
\text { virus }\end{array}$ & Enveloped & & Correlated \\
\hline Schaffer & 1976 & $\begin{array}{l}\text { Arch. virology 51.4: } \\
\text { 263-273. }\end{array}$ & Influenza A & Enveloped & & Least stable at $50 \%$ \\
\hline Elazhary & 1979 & $\begin{array}{l}\text { Can J Comp Med. } \\
43 \text { (2): } 158-67 .\end{array}$ & $\begin{array}{l}\text { Infectious bovine } \\
\text { rhinotracheitis }\end{array}$ & Enveloped & Variable & $\begin{array}{l}\text { Variable, usually } \\
\text { anticorrelated }\end{array}$ \\
\hline Elazhary & 1979 & $\begin{array}{l}\text { Can J Comp Med. } \\
\text { 43: } 305-312\end{array}$ & Bovine adenovirus 3 & Non-enveloped & Anticorrelated & Correlated \\
\hline Elazhary & 1979 & $\begin{array}{l}\text { Can J Comp Med. } \\
\text { 43: } 295-304\end{array}$ & $\begin{array}{l}\text { Bovine parainfluenza } \\
\text { type } 3\end{array}$ & Enveloped & Anticorrelated & Anticorrelated \\
\hline Karim & 1985 & $\begin{array}{l}\text { Can J Comp Med. } \\
31 \text { (11): 1058-61 }\end{array}$ & Rhinovirus 14 & Non-enveloped & & Correlated \\
\hline ljaz & 1985 & $\begin{array}{l}\text { J Gen Virol. } 66 \text { (Pt } \\
\text { 12): } 2743-8 \text { (1985). }\end{array}$ & $\begin{array}{l}\text { Human coronavirus } \\
229 \mathrm{E}\end{array}$ & Enveloped & Weak anticorellation & Peaks at $50 \%$ \\
\hline Schoenbaum & 1990 & $\begin{array}{l}\text { Am J Vet Res. } 51 \\
\text { (3): } 331-3(1990)\end{array}$ & Pseudorabies & Enveloped & Weak anticorellation & Peaks at $55 \%$ \\
\hline
\end{tabular}

Table 3: Laboratory studies of the survival of viruses in aerosols. It has been suggested (E2) that e.g. influenza seasonality is the result of the greater stability of flu virions in cold, dry conditions [ 2 Tamerius]. In the 12 studies shown, virus aerosols were introduced into rotating drums (the rotation stops the virions from settling) and the stability of virions was measured in air of different humidities. Note that several respiratory viruses (including influenza virus) are indeed more stable in dry air, but that several others, including rhinovirus and adenovirus, are much more stable in moist air. 


\section{References}

1. Hope-Simpson RE. Epidemic mechanisms of type A influenza. Epidemiology \& Infection. 1979 Aug;83(1):11-26. https://www.cambridge.org/core/journals/epidemiology-andinfection/article/epidemic-mechanisms-of-type-ainfluenza/34D7D883C245BDA6879D3B73CE7D6E14

2. Tamerius J, Nelson MI, Zhou SZ, Viboud C, Miller MA, Alonso WJ. Global influenza seasonality: reconciling patterns across temperate and tropical regions. Environmental health perspectives. $2011 \mathrm{Apr} ; 119(4): 439-45$. https://ehp.niehs.nih.gov/doi/full/10.1289/ehp.1002383

3. Shaw Stewart PD. Seasonality and selective trends in viral acute respiratory tract infections. Medical hypotheses. 2016 Jan 1;86:104-19.

https://www.sciencedirect.com/science/article/abs/pii/S030698771500417X

4. Eccles R. Why is temperature sensitivity important for the success of common respiratory viruses?. Reviews in Medical Virology. 2020 Aug 10:e02153. https://onlinelibrary. wiley.com/doi/full/10.1002/rmv.2153

5. Lwoff A. Factors influencing the evolution of viral diseases at the cellular level and in the organism. Bacteriological Rev 1959;23(3):109.

6. Richman DD, Murphy BR. The association of the temperature-sensitive phenotype with viral attenuation in animals and humans: implications for the development and use of live virus vaccines. Rev Infect Dis 1979;1(3):413-33.

6b. McFadden Jr ER, Pichurko BM, Bowman HF, Ingenito ED, Burns ST, Dowling NE, Solway JU. Thermal mapping of the airways in humans. Journal of applied physiology. $1985 \mathrm{Feb}$ 1;58(2):564-70. https://journals.physiology.org/doi/abs/10.1152/jappl.1985.58.2.564

6c. Google flu search. Retrieved August 2015. Google Flu Trends was a web service operated by Google that attempted to make predictions about influenza activity. After Google ceased publishing Flu Trends in August 2015, the graphical data for related searches was still available as "Google flu search".

7. Hope-Simpson RE, book. The transmission of epidemic influenza. Springer Science \& Business Media; 2013 Nov 11. See e.g. page 37.

8. Hope-Simpson RE. The role of season in the epidemiology of influenza. Epidemiology \& Infection. $1981 \mathrm{Feb} ; 86(1): 35-47$. https://www.cambridge.org/core/journals/epidemiology-andinfection/article/role-of-season-in-the-epidemiology-ofinfluenza/618AD6FF75DBD12ECBA7A084DE5E4D9E

9. Van Loghem JJ. An epidemiological contribution to the knowledge of the respiratory diseases. Epidemiology \& Infection. 1928 Aug;28(1):33-54.

https://www.cambridge.org/core/journals/epidemiology-and-infection/article/anepidemiological-contribution-to-the-knowledge-of-the-respiratorydiseases/D2549C91F05C00C100E8A2278859886C

10. Lidwell OM, Morgan RW, Williams RE. The epidemiology of the common cold IV. The effect of weather. Epidemiology \& Infection. 1965 Sep;63(3):427-39.

https://www.cambridge.org/core/journals/epidemiology-and-infection/article/epidemiology-ofthe-common-cold-iv-the-effect-of-weather/50274E6719E1C84519EFD2D9F6F76E1A

11. Hajat S, Bird W, Haines A. Cold weather and GP consultations for respiratory conditions by elderly people in 16 locations in the UK. European journal of epidemiology. 2004 Oct 1;19(10):959-68. https://link.springer.com/article/10.1007/s10654-004-5731-4

12. Kormuth KA, Lin K, Prussin AJ, Vejerano EP, Tiwari AJ, Cox SS, Myerburg MM, Lakdawala SS, Marr LC. Influenza virus infectivity is retained in aerosols and droplets independent of relative humidity. The Journal of infectious diseases. $2018 \mathrm{Jul}$ 24;218(5):739-47. https://academic.oup.com/iid/article/218/5/739/5025997?login=true

13. Paynter S, Ware RS, Sly PD, Williams G, Weinstein P. Seasonal immune modulation in humans: observed patterns and potential environmental drivers. Journal of Infection. 2015 Jan 1;70(1):1-0. https://www.sciencedirect.com/science/article/abs/pii/S0163445314002850

14. Milam DF, Smillie WG. A BACTERIOLOGICAL STUDY OF" COLDS" ON AN ISOLATED TROPICAL ISLAND (ST. JOHN, UNITED STATES VIRGIN ISLANDS, WEST INDIES. The Journal of experimental medicine. 1931 May 1;53(5):733-52. https://rupress.org/jem/articlestandard/53/5/733/10153/A-BACTERIOLOGICAL-STUDY-OF-COLDS-ON-AN-ISOLATED

15. Cannell JJ, Zasloff M, Garland CF, Scragg R, Giovannucci E. On the epidemiology of influenza. Virology journal. 2008 Dec 1;5(1):29. https://link.springer.com/article/10.1186/1743422X-5-29

16. du Prel JB, Puppe W, Gröndahl B, Knuf M, Weigl F, Schaaff F, Schaaff F, Schmitt HJ. Are meteorological parameters associated with acute respiratory tract infections?. Clinical 
infectious diseases. 2009 Sep 15;49(6):861-8. https://academic.oup.com/cid/article/49/6/861/333844?login=true

17. Viegas M, Barrero PR, Maffey AF, Mistchenko AS. Respiratory viruses seasonality in children under five years of age in Buenos Aires, ArgentinaA five-year analysis. Journal of Infection. 2004 Oct 1;49(3):222-8. https://www.sciencedirect.com/science/article/abs/pii/S0163445303001920

18. Chew FT, Doraisingham S, Ling AE, Kumarasinghe G, Lee BW. Seasonal trends of viral respiratory tract infections in the tropics. Epidemiology \& Infection. 1998 Aug;121(1):121-8. https://www.cambridge.org/core/journals/epidemiology-and-infection/article/seasonal-trendsof-viral-respiratory-tract-infections-in-the-tropics/FEDF5EB8031E2B4D47F84226D1DE5F1B

19. Ansart S, Pelat C, Boelle PY, Carrat F, Flahault A, Valleron AJ. Mortality burden of the 19181919 influenza pandemic in Europe. Influenza and other respiratory viruses. 2009 May;3(3):99-106. https://onlinelibrary.wiley.com/doi/full/10.1111/j.1750-2659.2009.00080.x

20. Wikipedia article: https://en.wikipedia.org/wiki/Viral hemorrhagic fever retrieved 04/01/2020.

21. Cressler CE, McLeod DV, Rozins C, Van Den Hoogen J, Day T. The adaptive evolution of virulence: a review of theoretical predictions and empirical tests. Parasitology. 2016 Jun;143(7):915-30. https://www.cambridge.org/core/journals/parasitology/article/adaptiveevolution-of-virulence-a-review-of-theoretical-predictions-and-empiricaltests/30EC8AB1717BF7A173CF5E051DBB498F

22. Fenner F, Marshall ID. A comparison of the virulence for European rabbits (Oryctolagus cuniculus) of strains of myxoma virus recovered in the field in Australia, Europe and America. Epidemiology \& Infection. 1957 Jun;55(2):149-91.

https://www.cambridge.org/core/journals/epidemiology-and-infection/article/comparison-ofthe-virulence-for-european-rabbits-oryctolagus-cuniculus-of-strains-of-myxoma-virusrecovered-in-the-field-in-australia-europe-andamerica/C0E389DA10F87F7472193E2791DC56C4

23. Ewald PW. Host-parasite relations, vectors, and the evolution of disease severity. Annual Review of Ecology and Systematics. 1983 Nov;14(1):465-85.

https://www.annualreviews.org/doi/abs/10.1146/annurev.es.14.110183.002341 ?journalCode= ecolsys. 1

24. Galanti M, Birger R, Ud-Dean M, Filip I, Morita H, Comito D, Anthony S, Freyer GA, Ibrahim $\mathrm{S}$, Lane B, Matienzo N. Rates of asymptomatic respiratory virus infection across age groups. Epidemiology \& Infection. 2019;147. https://www.cambridge.org/core/journals/epidemiologyand-infection/article/rates-of-asymptomatic-respiratory-virus-infection-across-agegroups/D8E75BDC5B16AEC88DB57CD9B291BB37

25. Galanti M, Birger R, Ud-Dean M, Filip I, Morita H, Comito D, Anthony S, Freyer GA, Ibrahim $\mathrm{S}$, Lane B, Ligon C. Longitudinal active sampling for respiratory viral infections across age groups. Influenza and other respiratory viruses. 2019 May;13(3):226-32. https://onlinelibrary.wiley.com/doi/full/10.1111/irv.12629

25b. Granados A, Goodall EC, Luinstra K, Smieja M, Mahony J. Comparison of asymptomatic and symptomatic rhinovirus infections in university students: incidence, species diversity, and viral load. Diagnostic microbiology and infectious disease. 2015 Aug 1;82(4):292-6. https://www.sciencedirect.com/science/article/abs/pii/S0732889315001510

25cTandale BV, Pawar SD, Gurav YK, Chadha MS, Koratkar SS, Shelke VN, Mishra AC. Seroepidemiology of pandemic influenza A (H1N1) 2009 virus infections in Pune, India. BMC infectious diseases. 2010 Dec 1;10(1):255. https://link.springer.com/article/10.1186/14712334-10-255

25d Papenburg J, Baz M, Hamelin MĖ, Rhéaume C, Carbonneau J, Ouakki M, Rouleau I, Hardy I, Skowronski D, Roger M, Charest H. Household transmission of the 2009 pandemic A/H1N1 influenza virus: elevated laboratory-confirmed secondary attack rates and evidence of asymptomatic infections. Clinical Infectious Diseases. 2010 Nov 1;51(9):1033-41. https://academic.oup.com/cid/article/51/9/1033/292322

25e Thai PQ, Welkers MR, Hang NL, Dung VT, Yen NT, Duong TN, Thoang DD, Trang HT, de Jong MD, Wertheim H, Hien NT. Pandemic H1N1 virus transmission and shedding dynamics in index case households of a prospective Vietnamese cohort. Journal of Infection. 2014 Jun 1;68(6):581-90. https://www.sciencedirect.com/science/article/pii/s0163445314000280

$25 f$ FOY HM, COONEY MK, ALLAN ID, ALBRECHT JK. Influenza B in households: virus shedding without symptoms or antibody response. American journal of epidemiology. 1987 Sep 1;126(3):506-15. https://academic.oup.com/aje/article-abstract/126/3/506/213433 
26. Cameron AS, Moore BW. The epidemiology of respiratory infection in an isolated Antarctic community. J Hyg 1968;66(03):427-37.

27. Allen TR, Bradburne AF, Stott EJ, Goodwin CS, Tyrrell DAJ. An outbreak of common colds at an Antarctic base after seventeen weeks of complete isolation. J Hyg 1973;71(04):657-67.

28. Muchmore HG, Parkinson AJ, Humphries JE, Scott EN, Mclntosh DA, Scott LV, et al. Persistent parainfluenza virus shedding during isolation at the South Pole. Nature $1981 ; 289: 187-9$.

29. Byambasuren O, Cardona M, Bell K, Clark J, McLaws ML, Glasziou P. Estimating the extent of true asymptomatic COVID-19 and its potential for community transmission: systematic review and meta-analysis. Available at SSRN 3586675. 2020 Apr 23. https://papers.ssrn.com/sol3/papers.cfm?abstract id=3586675

30. Tyrrell DAJ, Parsons R. Some virus isolations from common colds. III. Cytopathic effects in tissue cultures. Lancet 1960:239-42.

31. Bradburne AF, Bynoe ML, Tyrrell DA. Effects of a "new" human respiratory virus in volunteers. Br Med J 1967;3(5568):767.

32. Stern H, Tippett KC. Primary isolation of influenza viruses at 33 degrees $\mathrm{C}$. Lancet 1963;1(7294):1301.

33. Kung HC, Jen KF, Yuan WC, Tien SF, Chu CM. Influenza in China in 1977: recurrence of influenzavirus A subtype H1N1. Bull World Health Organ 1978;56(6):913.

34. Oxford JS, Corcoran T, Schild GC. Naturally occurring temperature-sensitive influenza A viruses of the H1N1 and H3N2 subtypes. J Gen Virol 1980;48(2):383-9.

35. Jardon M, Garnier A. PH, pCO2, and temperature effect on R-adenovirus production. Biotechnology progress. 2003;19(1):202-8. https://aiche.onlinelibrary.wiley.com/doi/abs/10.1021/bp025585a

36. Sato K, Watanabe O, Ohmiya S, Chiba F, Hayashi M, Suzuki T, Kawakami K, Nishimura H. Efficient isolation of human parainfluenza viruses 1 and 3 using MNT-1, a human malignant melanoma cell line system that exhibits an apparent cytopathic effect. Microbiology and immunology. 2016 Nov;60(11):801-5. https://onlinelibrary.wiley.com/doi/full/10.1111/13480421.12446

37. Sato K, Watanabe O, Ohmiya S, Chiba F, Suzuki A, Okamoto M, Younghuang J, Hata A, Nonaka H, Kitaoka S, Nagai Y. Efficient isolation of human metapneumovirus using MNT-1, a human malignant melanoma cell line with early and distinct cytopathic effects. Microbiology and immunology. $2017 \mathrm{Nov;61(11):497-506.}$

https://onlinelibrary.wiley.com/doi/full/10.1111/1348-0421.12542

38. Russell PH. Newcastle disease virus and two influenza viruses: differing effects of acid and temperature on the uptake of infectious virus into bovine and canine kidney cell lines. Arch Virol 1986;88(3-4):159-66.

39. Takashita E, Muraki Y, Sugawara K, Asao H, Nishimura H, Suzuki K, et al. Intrinsic temperature sensitivity of influenza $\mathrm{C}$ virus hemagglutinin-esterasefusion protein. J Virol 2012;86(23):13108-11.

40. Plotch SJ, Krug RM. Influenza virion transcriptase: synthesis in vitro of large, polyadenylic acid-containing complementary RNA. J Virol 1977;21(1):24-34.

41. Nagele A, Meier-Ewert H. Influenza-C-virion-associated RNA-dependent RNApolymerase activity. Biosci Rep 1984;4:703-6.

42. Muraki $Y$, Hongo $S$. The molecular virology and reverse genetics of influenza $C$ virus. Jpn $J$ Infect Dis 2010;63(3):157-65.

43. Ulmanen I, Broni B, Krug RM. Influenza virus temperature-sensitive cap (m7GpppNm)dependent endonuclease. Journal of virology. 1983 Jan 1;45(1):27-35. https://jvi.asm.org/content/45/1/27.short

44. Scholtgissek C, Rott R. Effect of temperature on the multiplication of an influenza virus. J Gen Virol 1969;5(2):283-90.

45. Kashiwagi T, Hara K, Nakazono Y, Hamada N, Watanabe H. Artificial hybrids of influenza A virus RNA polymerase reveal PA subunit modulates its thermal sensitivity. PLoS One. 2010 Dec 7;5(12):e15140. https://journals.plos.org/plosone/article?id=10.1371/journal.pone.0015140

46. Dalton RM, Mullin AE, Amorim MJ, Medcalf E, Tiley LS, Digard P. Temperature sensitive influenza $A$ virus genome replication results from low thermal stability of polymerase-cRNA complexes. Virology journal. 2006 Dec 1;3(1):58. https://link.springer.com/article/10.1186/1743-422X-3-58

47. Preble OT, Youngner JS. Temperature-sensitive viruses and the etiology of chronic and inapparent infections. J Infect Dis 1975;131(4):467-73. 
48. Frielle DW, Huang DD, Youngner JS. Persistent infection with influenza A virus: evolution of virus mutants. Virology 1984;138(1):103-17.

49. Liu B, Hossain M, Mori I, Kimura Y. Evaluation of a virus derived from MDCK cells infected persistently with influenza $A$ virus as a potential live-attenuated vaccine candidate in the mouse model. J Med Virol 2008;80(5):888-94.

50. Hope-Simpson RE, Golubev DB. A new concept of the epidemic process of influenza A virus. Epidemiol Infect 1987;99(01):5-54.

51. Gebauer F, De La Torre JC, Gomes I, Mateu MG, Barahona H, Tiraboschi B, et al. Rapid selection of genetic and antigenic variants of foot-and-mouth disease virus during persistence in cattle. J Virol 1988;62(6):2041-9.

52. Chu CM, Tian SF, Ren GF, Zhang YM, Zhang LX, Liu GQ. Occurrence of temperaturesensitive influenza A viruses in nature. J Virol 1982;41(2):353-9.

53. Narberhaus F, Waldminghaus T, Chowdhury S. RNA thermometers. FEMS Microbiol Rev 2006;30(1):3-16.

54. Chursov A, Kopetzky SJ, Leshchiner I, Kondofersky I, Theis FJ, Frishman D, et al. Specific temperature-induced perturbations of secondary mRNA structures are associated with the cold-adapted temperature-sensitive phenotype of influenza A virus. RNA Biol 2012;9(10):1266.

55. Shachor-Meyouhas $\mathrm{Y}$, Kassis I. Petechial rash with pandemic influenza (H1N1) infection. Pediatr Infect Dis J 2010;29(5):480.

56. Vano-Galvan S, Martorell A. Chilblains. CMAJ. 2012 Jan 10;184(1):67https://www.cmaj.ca/content/184/1/67

57. Massey PR, Jones KM. Going viral: A brief history of Chilblain-like skin lesions ("COVID toes") amidst the COVID-19 pandemic. In Seminars in Oncology 2020 May 23. WB Saunders. https://www.ncbi.nlm.nih.gov/pmc/articles/PMC7245293/

58. Andrewes $\mathrm{CH}$. Adventures Among Viruses. III. The Puzzle of the Common Cold. Reviews of infectious diseases. 1989 Nov 1;11(6):1022-8. https://www.jstor.org/stable/4455388?seq=1

59. Dowling HF, Jackson GG, Spiesman IG, Inouye T. Transmission of the common cold to volunteers under controlled conditions. III. The effect of chilling of the subjects upon susceptibility. American journal of hygiene. 1958;68(1):59-65. https://www.cabdirect.org/cabdirect/abstract/19592700063

60. Douglas Jr RG, Lindgren KM, Couch RB. Exposure to cold environment and rhinovirus common cold: failure to demonstrate effect. New England Journal of Medicine. 1968 Oct 3;279(14):742-7. https://www.nejm.org/doi/full/10.1056/NEJM196810032791404

61. Donaldson $\mathrm{G}$ (and the Eurowinter Group). Cold exposure and winter mortality from ischaemic heart disease, cerebrovascular disease, respiratory disease, and all causes in warm and cold regions of Europe. The Lancet. 1997 May 10;349(9062):1341-6. https://www.sciencedirect.com/science/article/abs/pii/S0140673696123382

62. Mudd S, Grant SB. Reactions to chilling of the body surface: experimental study of a possible mechanism for the excitation of infections of the pharynx and tonsils. The Journal of medical research. 1919 May;40(1):53. https://www.ncbi.nlm.nih.gov/pmc/articles/PMC2104350/

63. Bedford T, Riley S, Barr IG, Broor S, Chadha M, Cox NJ, Daniels RS, Gunasekaran CP, Hurt AC, Kelso A, Klimov A. Global circulation patterns of seasonal influenza viruses vary with antigenic drift. Nature. $2015 \mathrm{Jul} ; 523(7559): 217-20$. https://www.nature.com/articles/nature14460 